Review

\title{
Current Issues of Ash Deposition and Corrosion on Waste-to-Energy Plant
}

\author{
Hiroshi NAGANUMA ${ }^{*}{ }^{\dagger}$, Yoriaki SASAKI ${ }^{* 1}$, Ichiro NARUSE ${ }^{* 2}$, Ryo YoshIIE ${ }^{* 2}$, Yasuaki UeKI ${ }^{2}$, \\ Yoshihiko NinOMIYA ${ }^{* 3}$, Juan CHEN ${ }^{* 3}$, Manabu NoGUCHI ${ }^{* 4}$, and Hiromitsu CHO $* 4$ \\ (Received August 4, 2016)
}

\author{
廃棄物発電設備の灰付着と腐食に関する現状と課題 \\ 長沼 宏* ${ }^{\dagger}$, 佐々木頼明 ${ }^{2}$, 成瀬一郎 ${ }^{2}$, 義家 亮 ${ }^{2}$, 植木保昭 ${ }^{2}$, \\ 二宮善彦*3, Juan $\mathrm{CHEN}^{* 3}$, 野口 学*4, 長 洋光*4
}

\begin{abstract}
Some ash particles in solid wastes adhere on the heat exchanger tube surfaces inside incinerators. The ash deposition may cause such troubles, heat transfer inhibition, operational problems and high temperature corrosion. The authors have conducted the fundamental research for a surface treatment technology, using a thermal spray coating technique to reduce the deposition and the corrosion. First, this paper reviewed the previous studies on the deposition and the corrosion, such as characteristics of wastes, formation of ash and mechanisms in the incinerators. Then, the corrosion mechanisms were reported by means of our analysis and thermo-equilibrium calculations of the interfaces between the tube surface and the deposition. Moreover, the recent countermeasures against the ash deposition and the hot corrosion were reviewed, and their effectiveness and feasibilities were evaluated.
\end{abstract}

廃棄物燒却プラントの熱交換器では管表面にごみ中の灰が付着し, 伝熱阻害や運転障害, 高温腐食などの問題を 引き起こす可能性がある。それらの課題解決に向けて, 著者らは灰付着・高温腐食低減を可能とする伝熱管の表面 改質技術開発に関する基礎的な研究を実施した。本報では，廃棄物焼却炉内での死付着・高温腐食の機構について レビューするとともに, 本研究で実施した分析・熱力学平衡計算結果によって腐食機構を考察した。また, 最近の灰 付着·腐食の測定·評価方法や従来提案されている課題解決策を整理し，解決策の有効性や実現性について評価した。

\section{Key Words}

Waste-to-Energy plant, ash deposits, high temperature corrosion, thermal spray coating

\section{1. はじめに}

日本の廃棄物資源のうち一般廃棄物（ごみ）の中間処 理方法は, 直接焼却が $79.6 \%$ (平成 25 年度) ${ }^{1)}$ と高く, 焼却の際に発生する熱エネルギーの有効利用が重要な課 題になっている。また, 廃棄物（プラスチック類を除く）

※1 Tohoku Electric Power Engineering \& Construction, Co., Ltd.

53, Shinnakahori, Iidoi, Rifu, Miyagi-gun 981-0113, Japan

※2 Nagoya University

Furo-cho, Chikusa-ku, Nagoya, Japan

※3 Chubu University

1200, Matsumoto, Kasugai-shi, Aichi 487-8501, Japan

※ 4 Ebara Environmental Plant Co., Ltd.

11-1 Haneda Asahi-cho, Ohta-ku, Tokyo 144-0042, Japan

$\dagger \quad$ Corresponding author: th1995011@tohatu.co.jp
はライフサイクルの中で大気中の $\mathrm{CO}_{2}$ を増加させない『カー ボンニュートラル』な特性を持つバイオマスエネルギーと して, 平成 21 年 6 月に制定された『バイオマス活用推進 基本法』2)に基づき，環境省により『廃棄物系バイオマス 利用推進事業 (平成 23 年度〜 24 年度)』3) が実施され,
※1 東北発電工業株式会社
T 981-0113 宮城郡利府町飯土井字新中堀 53
※2 名古屋大学
于 464-8603 名古屋市千種区不老町
$※ 3$ 中部大学
T 487-8501 愛知県春日井市松本町 1200
※4 荏原環境プラント株式会社
广 144-0042 東京都大田区羽田旭町 11-1 
クリーンエネルギー源としてさらなる利用効率の向上が期 待されている。そのため, 発電設備を付带する廃棄物焼 却プラントは, 貴重な分散型地域エネルギー源として導 入が推進されている。しかし, 廃棄物発電設備に扔いて 熱エネルギーを回収する廃熱ボイラでは，スラッギングや ファウリングと呼ばれる灰付着に起因した伝熱阻害や運 転障害が生じて扔り，発電効率は現状で平均 $12.03 \%{ }^{11)}$ と 低水準で推移している。また，これらの付着灰除去のた めに, 場合によっては数ヶ月に一度の割合で開放点検を 行なわなければならず，施設の稼働率低下も余儀なくされ ている。さらに, 回収する熱エネルギーを蒸気に変換す る発電設備に扔いて発電効率向上を図るためには, 熱力 学サイクル上, 蒸気の高温化を必要とするが, 前述した灰 付着のみならず廃棄物中に含有する塩化物等に起因した 激しい高温腐食によって実現はできていない。

これらの課題に対し, 当時の通産省 (MITI) と（独） 新エネルギー産業技術総合開発機構（NEDO）により, 高効率廃棄物発電システムに関する技術開発が精力的に 実施された (平成 3 年度〜平成 11 年度) ${ }^{4}$ 。 特に, 高温 高効率焼却炉や耐腐食性過熱器管材料を中心に技術開 発が行なわれた結果，高蒸気条件 $\left(500^{\circ} \mathrm{C}, 9.8 \mathrm{MPa}\right)$ に よる発電設備の新設に繋げるとともに, 高温腐食機構の 解明や伝熱管に扔ける肉盛溶接・溶射技術の躍進に貢献 した。同プロジェクトでもその有用性を期待された表面改 質技術のひとつである溶射技術は，様々な運用条件やプ ラントに柔軟に対応できるとともに，既設の伝熱管に対し ても施工できることから，前述した低い発電効率を余儀 なくされているプラントに対しても，何らかの課題解決策 を提示できる可能性を示唆している。

一方, 著者らの研究グループでは, すでに石炭火力プ ラントに扔いて，溶射技術を用いた灰付着低減に関する 表面改質技術を開発して扔り 5) 6), 灰付着量制御に関す る知見を蓄積してきた。そのため, 著者らのグループは 環境省プロジェクト（環境研究総合推進費）により，平成 24 年度から 26 年度にかけて溶射技術を用いた灰付着低 減技術の基礎的研究を実施し, 廃棄物発電設備における 灰付着機構とその低減技術に関する調査と知見の蓄積, 材料開発等を図った7)。

本報では, その研究で得られた成果の一部として, 廃 棄物焼却プラントにおける腐食と灰付着に関する知見につ いて既往研究の事例とともに概説する。

\section{1 燃料としての特徵}

廃棄物を発電用のエネルギー源として捉えた場合，全 国各地に分散した比較的高い発熱量を持った燃料として 位置づけることができる。また，プラスチック類以外は燃 焼時の二酸化炭素排出量の算定から除外できるなど, 電
源確保や環境負荷低減という観点からも付加価值の高い 燃料であるといえる。ここで, 廃棄物を含めた各燃料に ついて, 発熱量 (低位) と燃料中に含まれる硫黄分, 塩 素分を整理したものを図1に示す8～～10)。本図より，廃棄 物は塩素濃度が硫黄よりも高いことが分かり, これが後 述する腐食や灰付着機構に大きく影響することになる。一 方, 石炭 (瀝青炭) は廃裹物とは反対に硫黄濃度が塩素 よりも高いことから，燃焼中に発生するアルカリ塩化物が 比較的融点の高い硫酸塩へと変化しやすい条件が形成さ れることになる。このことは, 付着した塩によって引き起 こされる伝熱管の腐食機構ならびに灰付着を引き起こす アルカリ化合物の伝熱面への凝縮機構にも影響する。ま た，木質バイオマス燃料では塩素濃度が硫黄と同程度で あることから，廃棄物ほど塩化物による影響が深刻化す ることは少ない。

\section{2 灰の由来, 生成}

一般廃牽物発電設備に打ける灰付着・腐食を考元るう えで最も重要となる塩素は, 家庭系ごみの場合, 主に容 器包装やラップなどのプラスチックごみに由来しており, 全塩素の約 75\%を占めている ${ }^{11}$ 。ごみ中の塩素と実際に 伝熱面上の付着層に含まれる塩素の含有率には明確な相 関があるので 12) 13)，プラスチック混入率はプラント伝熱 管の寿命に直接影響する。しかし, 日本では持続可能社 会への転換の機運が高まり, 2000 年に循環型社会形成 基本法 ${ }^{14)}$ が制定されて以来，リサイクル関連法が施行さ れ，廃蓑物総量が減少している。プラスチックごみに関し ては，プラスチック容器包装が資源化されることで, 横浜 市を例に取ると焼却率が 96.4\%（2001 年度）から 50.0\% （2008 年度）に減少している ${ }^{15)}$ 。のことによる塩素の

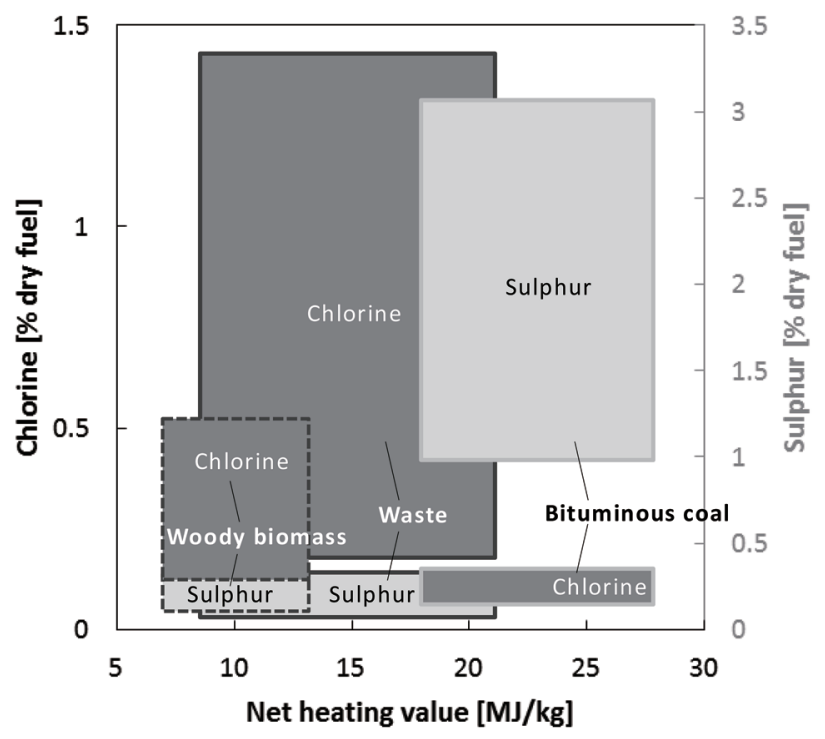

図 1 各種固体燃料の発熱量と燃料中の塩素・硫黄含有率 (dry) の比較 8) 10) 
減少は，伝熱管腐食量の低下という良い側面を持つ一方， ごみ発熱量・発電量の低下 ${ }^{16)}$ という負の側面も含むこと になる。

揮発性金属元素のうち, 灰付着・腐食に関係するもの として亜鉛が挙げられるが, これはめっきやポリ塩化ビニ ル (PVC), インク, 塗料, 顔料, ゴム, 植物栄養剤など に使用されており，加工木材にも微量含有している。燃 焼時の亜鉛の揮発は比較的低温から始まり，特にPVC

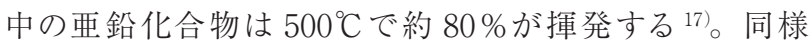
に問題となる鉛は, バッテリーやガラス製品, 電気器具, 電球，織物，ゴム，革などに含まれており，PVCの安定 剂としても使用されている。亜鉛と鉛の放出挙動は複雑 で，ガス組成，温度，灰組成で大きく変化し，一般的な 廃棄物焼却条件下ではガス中の $\mathrm{HCl}$ が多いためにこれら の金属元素は塩化物となることが多い18)。なお，アルカ リ金属 (Na や K ) が多い場合は, 亜鉛と鉛の塩化物生 成は抑制される。

アルカリ金属は, 塩化物, 炭酸塩等の形態, または有 機物と結合してごみ中に存在しており，それらは燃焼過程 で水酸化物, 酸化物および塩化物蒸気の形で放出され, 熱交換器内では一般的に気相で存在している。また，ア ルカリ金属は，家庭系ごみや紙類，ガラス製品，建築廃 材など多くの廃棄物に含まれており，焼却条件によるもの の燃焼後はガス中の $\mathrm{HCl}$ の影響により塩化物へと変化す る。しかし, 後述するとおり, ガス中の $\mathrm{SO}_{2} / \mathrm{SO}_{3}$ 濃度によっ て，硫酸化合物に変化し $\mathrm{HCl}$ を放出してしまう。さらに， アルカリ塩化物は灰付着・腐食機構に亜鉛や鉛と同様に 重要な役割を果たすことになる。

\section{3. 既往の灰付着・腐食機構と本研究で得られた知見 3.1 灰付着・腐食の機構}

\subsection{1 ガス腐食 (Active oxidation)}

図 2 に, 伝熱管表面上で生じる灰付着と腐食機構に関 する概略図を示す。本図は，既往文献 19）20)で整理され た基本反応式・模式図に，文献調査や本研究で得られた 腐食・灰付着機構に関する知見を追記して整理した。酸 化䨌囲気においては，伝熱管表面に密度が高く均一で熱 力学的に安定な酸化皮膜が形成され，それが酸素や他の ガス成分に対し一定の障壁となり，特に Cr 酸化物は高い 保護性を持つ。酸化皮膜の厚さは時間の 0.5 乗に比例す る放物線則に則った速度で成長するものの, $\mathrm{Cl}_{2}$ や $\mathrm{HCl}$ ガ スは酸化皮膜の空隙や亀裂を経路として内部へ拡散する 可能性があり，金属素地と酸化皮膜界面に到達した後， 金属素地と直接反応して塩化物を形成することになる。 通常の燃焼ガス䨌囲気では，塩素系ガス成分として $\mathrm{HCl}$ が安定して存在する温度域が広いものの, $\mathrm{Fe}_{2} \mathrm{O}_{3}, \mathrm{PbO}$, $\mathrm{CuO}$ などの金属酸化物が触媒となり, $\mathrm{HCl}$ を酸化してしま い腐食性の高い $\mathrm{Cl}_{2}$ ガスになってしまうこともある。この
反応は Deacon 反応 (図2 参照) と呼ばれ, 遅い反応であ り, かつ水蒸気分圧が高い場合には進行し難い。実際に, 水蒸気が腐食量を減少させるという事例もあり, これは式 （1）に示すDeacon 反応と図 2 に記載した Hargreaves 反 応を抑制するという機構で説明されている21)。しかし，前 述の触媒の存在下で, 廃棄物燃料中の成分の不安定性, 変動性を考慮すると, 本反応による $\mathrm{Cl}_{2}$ ガス生成は十分 起こりうるものと考えられている。

$$
2 \mathrm{HCl}(\mathrm{g})+1 / 2 \mathrm{O}_{2}(\mathrm{~g}) \rightarrow \mathrm{Cl}_{2}(\mathrm{~g})+\mathrm{H}_{2} \mathrm{O}(\mathrm{g})
$$

金属と酸化皮膜界面では酸素の濃度が低いため, 式(2) から（4）が示すように, $\mathrm{FeCl}_{2}$ や $\mathrm{CrCl}_{2}$ といった塩化物が 熱力学的に生成し易い条件となる。生成されたこれらの 金属塩化物は, 金属素地と酸化皮膜間では高い蒸気圧に なるため揮発が進むことになる。一般的に，対象となる 塩化物の蒸気圧が $10.13 \mathrm{~Pa}\left(10^{-4} \mathrm{~atm}\right)$ 以上の時に腐食 量が大きくなるとされており，その時の温度が圧力の指数 をとって $\mathrm{T}_{4}$ として整理されている(後述)。この $\mathrm{T}_{4}$ は融 点 $\mathrm{T}_{\mathrm{m}}$ より常に低い傾向にあり，これが融液が無い場合 でも高い減肉を引き起こす論拠となっている ${ }^{22) 。 ~}$

$$
\begin{aligned}
& \mathrm{M}(\mathrm{s})+\mathrm{Cl}_{2}(\mathrm{~g}) \rightarrow \mathrm{MCl}_{2}(\mathrm{~s}) \\
& \mathrm{M}(\mathrm{s})+2 \mathrm{HCl}(\mathrm{g}) \rightarrow \mathrm{MCl}_{2}(\mathrm{~g})+\mathrm{H}_{2}(\mathrm{~g})
\end{aligned}
$$$$
\mathrm{MCl}_{2}(\mathrm{~s}) \rightarrow \mathrm{MCl}_{2}(\mathrm{~g}) \quad \mathrm{M}: \mathrm{Fe} \text { or } \mathrm{Cr}
$$

これらの金属塩化物蒸気は外側へ拡散し，金属界面 から遠ざかるにつれて周囲の酸素分圧が上昇するため, 式 （5）および (6)のように金属酸化物へと変化する（図2【A】 参照）。このように形成された酸化物は上記の本来の酸化 皮膜と比較すると空隙が多く脆い構造となるため，ガス 成分の拡散を容易にする。また，溶融塩に対する耐食性 を低下させるとともに，この空隙を多く含む構造は，酸化 皮膜の剥離を促進させる。そのため，塩化物による腐食 減肉は放物線則ではなく時間とともに直線的に増加する 直線則に近づく傾向となる。

$$
\begin{array}{r}
3 \mathrm{MCl}_{2}(\mathrm{~g})+2 \mathrm{O}_{2}(\mathrm{~g}) \rightarrow \mathrm{M}_{3} \mathrm{O}_{4}(\mathrm{~s})+3 \mathrm{Cl}_{2}(\mathrm{~g}) \\
2 \mathrm{MCl}_{2}(\mathrm{~g})+(3 / 2) \mathrm{O}_{2}(\mathrm{~g}) \rightarrow \mathrm{M}_{2} \mathrm{O}_{3}(\mathrm{~s})+2 \mathrm{Cl}_{2}(\mathrm{~g}) \\
\mathrm{M}: \mathrm{Fe} \text { or } \mathrm{Cr}
\end{array}
$$

これらの反応 (後述する $\mathrm{Cl}_{2}$ 生成反応, 式 (11), (13) および（14）を含む）で生成された $\mathrm{Cl}_{2}$ ガスは基本的に外 側へ拡散するが, 一部が金属素地へ向かい前述のサイク ルが繰り返される。この腐食サイクルは Active Oxidation と呼ばれ，潜伏時間無しに開始される。このときの腐食 量は，酸化物と塩化物の形成量の関係によって，酸化に よる重量増と塩化物の揮発による重量減の放物線一直線 則，または塩化物生成の線形則に従う 22)。

\subsection{2 その他のガス腐食}

$\mathrm{HCl}$ も保護酸化皮膜の消失, 破壊に影響し, 揮発性の 高い $\mathrm{FeCl}_{3}$ が生成して腐食速度を加速させる。ガス中に $\mathrm{HCl}$ が存在しない場合は, 連続的な空隙の無い酸化皮 膜が形成されるものの, $0.1 \mathrm{vol} \%$ $\mathrm{HCl}$ 存在下では空隙 


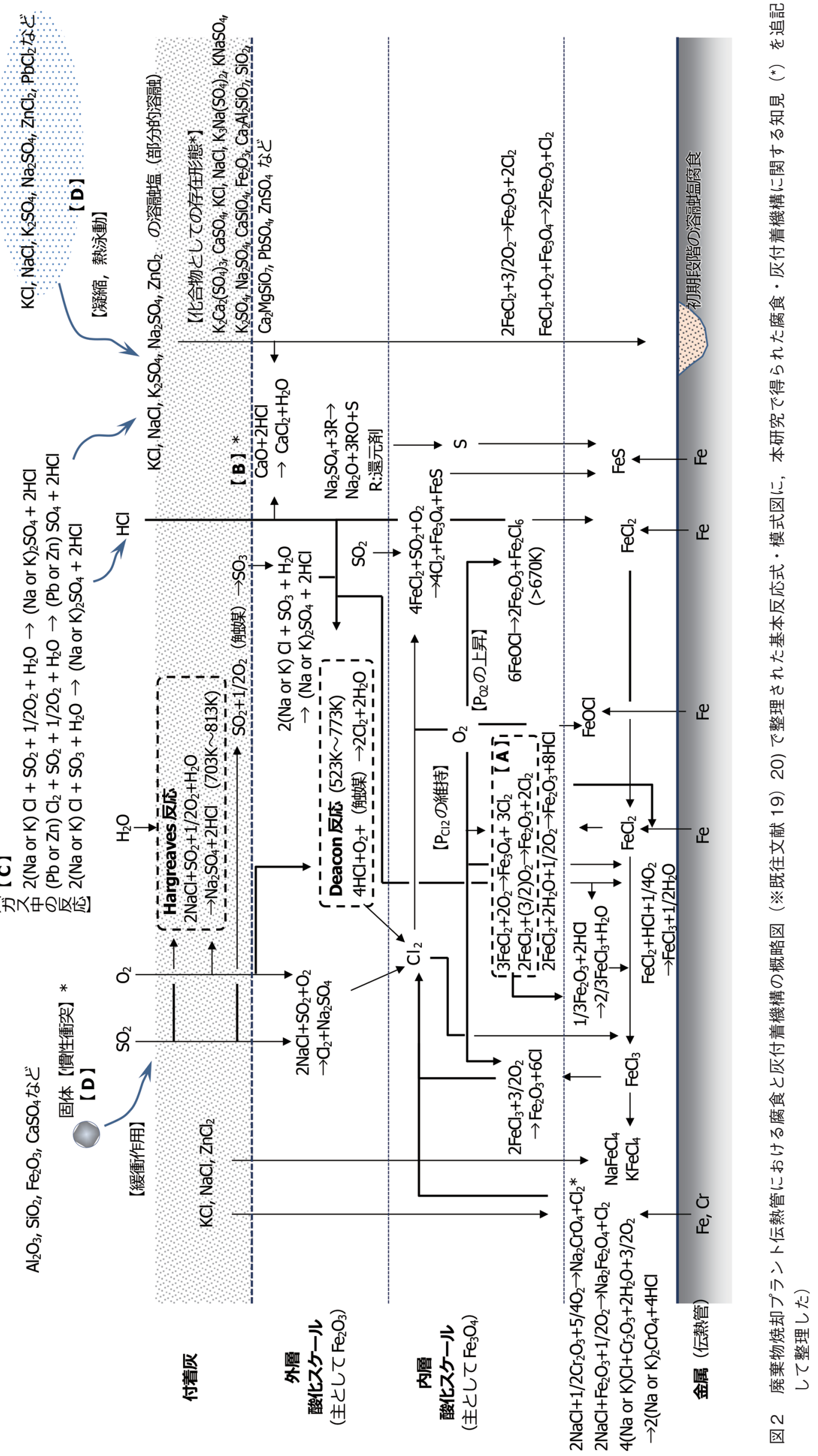


の多いHematite 層が生成する。しかし，酸化皮膜は未 だ連続的である。 $\mathrm{HCl}$ が $0.2 \mathrm{vol} \%$ に至ると酸化皮膜はポー ラスで不連続的になり，0.8 vol\%では Hematite 層は完全 に崩壊し，また Magnetite 層は不規則でポーラスとなる。 $2.0 \mathrm{vol} \%$ に至ると全ての酸化皮膜が破壊し, 腐食性ガス は $\mathrm{FeO}$ または素地と直接反応してしまう23)。

一方, 還元䨌囲気では, 塩化水素ガスが直接金属素地 と反応し，金属塩化物が生成される。この場合の腐食サ イクルは金属塩化物の揮発に支配されるので，腐食速度 は䨌囲気温度の影響を強く受ける。 $\mathrm{HCl} / \mathrm{N}_{2}$ における腐食 速度則は，塩化物の成長速度と，生成した塩化物が揮発 する速度のいずれが律速になるかに依存している。500 以下では金属素地上に保護性のある鉄塩化物が形成さ れるため，腐食反応による重量増加は時間に対して放物 線則になり，一方，それより高温域では重量が放物線則 で増加した後，時間に対し直線的に減少する。おおよそ $800^{\circ} \mathrm{C}$ 以上では揮発速度が速いので，塩化物の成長速度 が律速となり，腐食減量は時間に対して直線的になる ${ }^{19)}$ 。 還元雲囲気ではガス中の CO も腐食に影響し，高 CO で は $\mathrm{HCl}$ 濃度が $200 \mathrm{ppm}$ を超えると COによる腐食減量は 放物線則から直線則に移行するといわれている 24 。

酸素と $\mathrm{HCl}$ が共存する場合, 低融点 $\mathrm{FeCl}_{3}$ の昇華によっ て式（7）のとおり加速的な腐食が生じる。一方で，還元 雲囲気では保護酸化皮膜が存在しないため, $\mathrm{HCl}$ による $\mathrm{Fe}$ の腐食速度は高くなるという報告事例もある ${ }^{19)}$ 。また, 鉄酸化物スケールも $\mathrm{HCl}$ 存在下では式 (8) に従って $\mathrm{FeCl}_{3}$ が生成してしまう。

$$
\begin{aligned}
\mathrm{FeCl}_{2}(\mathrm{~g})+ & \mathrm{HCl}(\mathrm{g})+1 / 4 \mathrm{O}_{2}(\mathrm{~g}) \\
& \rightarrow \mathrm{FeCl}_{3}(\mathrm{~s}, \mathrm{l})+1 / 2 \mathrm{H}_{2} \mathrm{O}(\mathrm{g})
\end{aligned}
$$

$1 / 3 \mathrm{Fe}_{2} \mathrm{O}_{3}(\mathrm{~s})+2 \mathrm{HCl}(\mathrm{g}) \rightarrow 2 / 3 \mathrm{FeCl}_{3}(\mathrm{~s}, \mathrm{l})+\mathrm{H}_{2} \mathrm{O}(\mathrm{g})(8)$

付着層における溶融塩化物も腐食に影響し，その金属 化合物としては $\mathrm{Na}, \mathrm{K}, \mathrm{Pb}, \mathrm{Zn}$ が関与するという報告が 最も多い。アルカリ塩化物による腐食は $400^{\circ} \mathrm{C}$ 以上で大き くなる。その他に, $\mathrm{Ca}$ も $\mathrm{HCl}$ ガスと反応して他の塩化物 と共晶物を構成し低融点塩化物を生成する（図2【B】参 照)。式 (9)の反応は $550^{\circ} \mathrm{C} \sim 700^{\circ} \mathrm{C}$ で進行し, 過熱器 管上に付着物を形成しやすいと指摘されているものの ${ }^{25)}$, 著者らの行なった実機の付着灰分析結果（後述）からは, それよりも低いメ夕ル温度の蒸発管と過熱器管上の両方 からもそれらが検出された。また，後述するとおり，熱力 学平衡計算上でもそれらの化合物が伝熱管一付着層の界 面で融液として存在するという結果を計算で得た。

$$
\mathrm{CaO}(\mathrm{s})+2 \mathrm{HCl}(\mathrm{g}) \rightarrow \mathrm{CaCl}_{2}(\mathrm{~s})+\mathrm{H}_{2} \mathrm{O}(\mathrm{g})
$$

塩化物蒸気圧が高い場合，灰付着層とその近傍の金 属素地表面で前述のガス腐食と似た機構の腐食が誘引 される。 $\mathrm{Cl}_{2}$ ガスの生成は，金属と腐食層の塩化物間の 反応により，またはアルカリ塩化物の硫酸化合物への変 化によって起こる。また, 灰付着層内の塩化物は低融点
共晶物を生成し, 酸化皮膜の融解を促進する。塩化物 は固相であっても灰付着層内で $\mathrm{SO}_{2} / \mathrm{SO}_{3}$ ガスと反応し硫 酸化合物を生成するが，水蒸気が共存する場合は $\mathrm{HCl}$ ガス，無い場合は $\mathrm{Cl}_{2}$ ガスも生成する。十分な滞留時間 や一定の $\mathrm{SO}_{2} / \mathrm{SO}_{3}$ 濃度であれば，伝熱管に付着する前 に硫酸化合物へ変化してしまう。この気相中の変化につ いては, Deuerling et al. が捕捉粒子の分析によって ${ }^{26)}$, Montgomery et al. ${ }^{27)}$ や Reichelt et al. ${ }^{28)}$ が付着灰の分析 によって確認しており, 後流側のガス中の $\mathrm{HCl}$ 濃度が増 大し, $\mathrm{SO}_{2}$ 濃度が減少することでも裏づけされている27)。 また，この反応については $\mathrm{Zn}$ や $\mathrm{Pb}$ といった重金属類に おいても凝縮量を評価することで確認されている29)。しか し, $\mathrm{SO}_{2} / \mathrm{SO}_{3}$ ガスの消費と $\mathrm{HCl}$ の放出，さらには対流伝 熱域を燃焼ガスが通過することによるガス温度の低下に よって，後流側のおおよそ $300^{\circ} \mathrm{C}$ 以下では灰付着層中の塩 化物含有率は高くなる26) 27)。これは，灰付着層がエコノ マイザ管上に成長したものであり，付着灰粒子は大部分 が固相で，後述するような融液がほとんど無いことに起因 する。この温度条件において小径で存在する粒子は, 気 相から凝縮した塩化物が多くなる傾向にあり，大径側は 珪酸塩や硫酸塩が多くなる。つまり, 塩化物含有率が高 い微粒子 $(1.0 \mu \mathrm{m} \text { 以下 })^{26)}$ 30) だけが熱泳動等で捕捉され, 慣性衝突する珪酸塩および硫酸塩系の粒子はほとんど管 上に捕捉されないうえに, アルカリ硫酸化合物はこの温 度域では熱力学的に安定ではないためである。さらに温 度が低下すると塩化物, 硫酸化合物含有率はともに減少 する。

アルカリ塩化物の硫酸塩への変化は速い速度で進行 し，灰付着層においては特に外側（ガス側）で生じる。 ここで，式（10）において硫酸化合物の生成が促進される ためには, 一定の $\mathrm{O}_{2}$ 濃度が必要となるので, 低 $\mathrm{O}_{2}$ 雲囲 気では塩化物に比べて融点の高い硫酸化合物への変化 が抑制され，厳しい腐食環境が創出されてしまう。

$2(\mathrm{Na}$ or $\mathrm{K}) \mathrm{Cl}(\mathrm{s})+\mathrm{SO}_{2}(\mathrm{~g})+1 / 2 \mathrm{O}_{2}(\mathrm{~g})+\mathrm{H}_{2} \mathrm{O}(\mathrm{g})$

$\rightarrow(\mathrm{Na}$ or $\mathrm{K}) 2 \mathrm{SO}_{4}(\mathrm{~s})+2 \mathrm{HCl}(\mathrm{g})$

$2(\mathrm{Na}$ or $\mathrm{K}) \mathrm{Cl}(\mathrm{s})+\mathrm{SO}_{2}(\mathrm{~g})+\mathrm{O}_{2}(\mathrm{~g})$

$$
\rightarrow(\mathrm{Na} \text { or } \mathrm{K}) 2 \mathrm{SO}_{4}(\mathrm{~s})+\mathrm{Cl}_{2}(\mathrm{~g})
$$

式（10）の反応で生成した $\mathrm{HCl}$ はほとんどがガス側へ放 出されるが，そのうち内部へ拡散したものによって，金属 塩化物 $\left(\mathrm{FeCl}_{2}, \mathrm{FeCl}_{3}\right)$ が生成される。この塩化物は前 述のガス腐食と近い反応で酸化物へ変化する際に $\mathrm{HCl}$ や $\mathrm{Cl}_{2}$ を生成し, 再び金属素地へ向かって腐食を助長してし まう。

$$
4 \mathrm{MCl}_{2}(\mathrm{~g})+4 \mathrm{H}_{2} \mathrm{O}(\mathrm{g})+\mathrm{O}_{2}(\mathrm{~g}) \rightarrow 2 \mathrm{M}_{2} \mathrm{O}_{3}(\mathrm{~s})+8 \mathrm{HCl}(\mathrm{g})
$$

式 (10) および式 (11) が示すように, これら固相の硫酸 化合物への変化は $\mathrm{SO}_{2}$ または $\mathrm{SO}_{3}$ によって起こるが, $\mathrm{SO}_{3}$ による反応が格段に速い。実際はガス中の $\mathrm{SO}_{3}$ 濃度はわ 
ずかであるものの, $\mathrm{Fe}_{2} \mathrm{O}_{3}$ などの金属酸化物が触媒となり $\mathrm{SO}_{2}$ から $\mathrm{SO}_{3}$ への転換を促進させていることが知られてい る ${ }^{25)}$ ここのことは, 灰付着層内部での塩化物の硫酸化合 物化を促し，金属表面に近い場所での塩素ガス生成につ ながる(図 2 【C】)。

一方, 塩化物の $\mathrm{SO}_{2} / \mathrm{SO}_{3}$ ガスとの反応による $\mathrm{Cl}_{2}$ ガス 発生については，塩化物の金属酸化物との反応による機 構も報告されている。これらの反応によって $\mathrm{Cl}_{2}$ 分圧が高 くなり, 前述の腐食反応と同様に進行する。また, 式 (13) 〜（15）が示すように，アルカリ塩化物が伝熱管金属酸化 物と直接反応し, 保護性の無い固相を形成するとともに $\mathrm{Cl}_{2}$ ガスや $\mathrm{HCl}$ ガスを生成する。特に, 高温域 $\left(600^{\circ} \mathrm{C}\right)$ ではオーステナイト系ステンレス材料に扔ける Cr 酸化物と アルカリ塩化物が反応し, 保護性の低い皮膜の生成・ $\mathrm{Cr}$ 酸化物の再生成をと执して, 伝熱管表面に上層 (Hematite) と下層 $(\mathrm{Fe}, \mathrm{Cr}, \mathrm{Ni}$ などで構成されるスピネル形酸化物) の二重層を形成させてしまう31)。一方，アルカリ硫酸化 合物は同温度域では $\mathrm{Cr}$ 酸化物とは反応しないため, 腐 食は増大しない。

$$
\begin{aligned}
& 2 \mathrm{NaCl}(\mathrm{s}, \mathrm{l})+1 / 2 \mathrm{Cr}_{2} \mathrm{O}_{3}(\mathrm{~s})+5 / 4 \mathrm{O}_{2}(\mathrm{~g}) \\
& \rightarrow \mathrm{Na}_{2} \mathrm{CrO}_{4}(\mathrm{~s}, \mathrm{l})+\mathrm{Cl}_{2}(\mathrm{~g}) \\
& 2 \mathrm{NaCl}(\mathrm{s}, \mathrm{l})+\mathrm{Fe}_{2} \mathrm{O}_{3}(\mathrm{~s})+1 / 2 \mathrm{O}_{2}(\mathrm{~g}) \\
& \rightarrow \mathrm{Na}_{2} \mathrm{Fe}_{2} \mathrm{O}_{4}(\mathrm{~s}, \mathrm{l})+\mathrm{Cl}_{2}(\mathrm{~g}) \\
& 4(\mathrm{Na} \text { or } \mathrm{K}) \mathrm{Cl}(\mathrm{s})+\mathrm{Cr}_{2} \mathrm{O}_{3}(\mathrm{~s})+2 \mathrm{H}_{2} \mathrm{O}(\mathrm{g})+3 / 2 \mathrm{O}_{2}(\mathrm{~g})
\end{aligned}
$$

$$
\rightarrow 2(\mathrm{Na} \text { or } \mathrm{K}) 2 \mathrm{CrO}_{4}(\mathrm{~s})+4 \mathrm{HCl}(\mathrm{g})
$$

式（16）の上うに，Cr含有率の高い伝熱管に抢ける粒 界部のクロム炭化物が選択的にアルカリ塩化物で腐食さ れる反応も報告されている。腐食反応が下式の機構か, 粒界の $\mathrm{Cr}$ 欠乏層の選択的腐食かは判断が難しいが，い ずれにしても粒界付近に打ける腐食反応は後述するとお り報告事例が多く, $\mathrm{CrCl}_{3}$ の揮発，または伝熱管一酸化 物界面に打ける O2-の活量増大に伴う $\mathrm{CrO}_{4}{ }^{2-}$ の溶解 32$)$ の 観点で考察されている。

$$
\begin{aligned}
& \mathrm{Cr}_{23} \mathrm{C}_{6}(\mathrm{~s})+46 \mathrm{NaCl}(\mathrm{g})+52 \mathrm{O}_{2}(\mathrm{~g}) \\
& \quad \rightarrow 23 \mathrm{Na}_{2} \mathrm{CrO}_{4}(\mathrm{~s}, \mathrm{l})+6 \mathrm{CO}_{2}(\mathrm{~g})+23 \mathrm{Cl}_{2}(\mathrm{~g})
\end{aligned}
$$

\section{1 .3 溶融塩の影響}

塩化物を含む共晶低融点物質が腐食に関係することも 多くの報告例があり, 灰成分の溶融挙動と扊付着性につ いて，石炭と同様にスラッギング指標を用いて評価した事 例もある ${ }^{33)}$ 。灰付着機構としては，蒸気の凝縮，飛灰の 物理的な衝突・付着（図2【D】）ならびにガス成分とす でに付着している成分との反応が関与している。ストーカ 式㧍よび流動床式の両タイプの燃焼炉内に抄いて飛散し ている灰粒子の粒度分布は $0.5 \mu \mathrm{m}$ と $300 \mu \mathrm{m}$ にピークを 持つバイモーダルであり, 微粒子側には気相から凝縮し たアルカリ塩化物が, 粗粒子側には $\mathrm{Si}$ や Ca が多く含まれ ている 26) 30)。灰付着速度や灰組成に関してはガス温度が 影響し，伝熱管との界面における温度勾配は塩化物など
のガス中の揮発成分の凝縮の駆動力となるため, ガス温 度と伝熱管表面温度の温度差が大きい部位では塩化物 濃度が高く, かつ融点も低下する傾向があり 20), この温

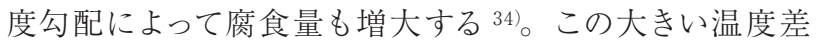
は凝縮の駆動力になるだけでなく，腐食生成物の外方拡 散や気化も促進させ，前述の Active Oxidation を促進さ せる。また，流動層プラントにおいて流動層温度を $870^{\circ} \mathrm{C}$ から $720^{\circ} \mathrm{C}$ に低下させると灰付着量が減少し, 塩化物含 有量も併せて減少したという報告もある ${ }^{35)}$ 。この時の灰 付着層内の元素分析結果から, 灰付着量が多い時は塩化 物含有率上昇に併せて高融点化合物を形成する $\mathrm{Si}$ や $\mathrm{Ca}$ 量も増加していることから, 低融点の溶融塩の物理的緩 衝作用で固相粒子を捕捉しているものと予想できる。

廃棄物焼却場における加速的な腐食が開始される温度 については，条件（溶融塩成分，温度，伝熱管材質等） によって様々であるものの，いずれの報告事例において も，溶融塩の融解が開始される温度に関連付けて説明さ れている。例えば, Bryers は重金属類塩化物を含む共晶 系の塩による腐食が $443^{\circ} \mathrm{C}$ 以上で加速されることを示して おり ${ }^{24)}$, Salmenoja et al. は $430^{\circ} \mathrm{C} て ゙$ 付着物の初期溶解温 度を確認している ${ }^{36)}$ 。本研究でも図3に示すと打り, 腐 食試験等に供したアルカリ塩化物－硫酸化合物－塩化鉛 の複合塩の示差走查熱量計 (DSC) 分析で, 約 $420^{\circ} \mathrm{C}$ に て融解による大きな吸熱反応を確認している。また，Lai et al. はメタル温度が $430^{\circ} \mathrm{C}$ を超える (ガス温度が $760^{\circ} \mathrm{C}$ のとき）と，腐食速度が急上昇すると報告している37)。 表122）38）が示すように，一般的に付着灰成分のうち融点 が $500^{\circ} \mathrm{C}$ 以下にある低融点共晶化合物の多くはアルカリ 金属塩化物と $\mathrm{Zn}, \mathrm{Pb}$ 等の重金属塩化物との共晶系で構 成されることが知られており，これらが溶融状態で最も激

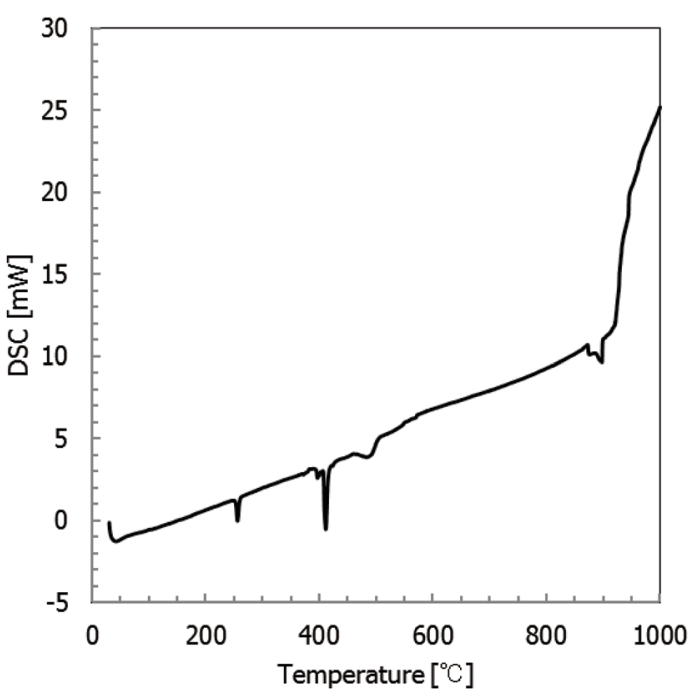

図3 示差走査熱量計（DSC）による吸熱反応測定結果（塩 $22.5 \mathrm{~mol} \% \mathrm{NaCl}-22.5 \mathrm{~mol} \% \mathrm{KCl}-22.5 \mathrm{~mol}^{2} \mathrm{Na}_{2} \mathrm{SO}_{4}$ $-22.5 \mathrm{~mol}_{0} \mathrm{~K}_{2} \mathrm{SO}_{4}-10 \mathrm{~mol}_{\mathrm{OPbCl}}$ ) 
表 1 塩化物共晶系の融点一覧 22) 38)

\begin{tabular}{|c|c|c|c|}
\hline Salt mixture & Melting point $\left[{ }^{\circ} \mathrm{C}\right]$ & Salt mixture & Melting point $\left[{ }^{\circ} \mathrm{C}\right]$ \\
\hline $27 \mathrm{NaCl}-73 \mathrm{FeCl}_{3}$ & 156 & $35 \mathrm{ZnCl}_{2}-48 \mathrm{NaCl}-17 \mathrm{PbCl}_{2}$ & 350 \\
\hline $66 \mathrm{ZnCl}_{2}-34 \mathrm{FeCl}_{3}$ & 200 & $47 \mathrm{KCl}-53 \mathrm{FeCl}_{2}$ & 355 \\
\hline $68 \mathrm{ZnCl}_{2}-32 \mathrm{KCl}$ & 230 & $37 \mathrm{NaCl}-63 \mathrm{FeCl}_{2}$ & 370 \\
\hline $56 \mathrm{ZnCl}_{2}-30 \mathrm{NaCl}-14 \mathrm{PbCl}_{2}$ & 238 & $17 \mathrm{ZnCl}_{2}-59 \mathrm{KCl}-24 \mathrm{PbCl}_{2}$ & 375 \\
\hline $51 \mathrm{ZnCl} l_{2}-43 \mathrm{KCl}-6 \mathrm{PbCl}_{2}$ & 238 & $36 \mathrm{NaCl}-39 \mathrm{KCl}-25 \mathrm{FeCl}_{2}$ & 380 \\
\hline $43 \mathrm{ZnCl}_{2}-49 \mathrm{KCl}-8 \mathrm{PbCl}_{2}$ & 250 & $\mathrm{~K}_{2} \mathrm{SO}_{4}-\mathrm{Na}_{2} \mathrm{SO}_{4}-\mathrm{ZnSO}_{4}$ & 384 \\
\hline $48 \mathrm{ZnCl}_{2}-52 \mathrm{KCl}$ & 250 & $36 \mathrm{NaCl}-47 \mathrm{PbCl}_{2}-17 \mathrm{CaCl}_{2}$ & 391 \\
\hline $82 \mathrm{ZnCl}_{2}-18 \mathrm{KCl}$ & 262 & $16 \mathrm{NaCl}-40 \mathrm{KCl}-44 \mathrm{PbCl}_{2}$ & 400 \\
\hline $84 \mathrm{ZnCl}_{2}-16 \mathrm{KCl}$ & 262 & $31 \mathrm{NaCl}-69 \mathrm{PbCl}_{2}$ & 410 \\
\hline $1 \mathrm{CaCl}_{2}-99 \mathrm{ZnCl} 2$ & 270 & $21 \mathrm{KCl}-79 \mathrm{PbCl}_{2}$ & 411 \\
\hline $39 \mathrm{ZnCl}_{2}-50 \mathrm{KCl}-11 \mathrm{PbCl}_{2}$ & 275 & $15 \mathrm{FeCl}_{2}-85 \mathrm{PbCl}_{2}$ & 421 \\
\hline $89 \mathrm{ZnCl}_{2}-11 \mathrm{ZnSO}_{4}$ & 300 & $31 \mathrm{ZnCl}_{2}-69 \mathrm{KCl}$ & 430 \\
\hline $73 \mathrm{ZnCl}_{2}-27 \mathrm{PbCl}_{2}$ & 300 & $9 \mathrm{CaCl}_{2}-91 \mathrm{PbCl}_{2}$ & 475 \\
\hline $58 \mathrm{ZnCl}_{2}-27 \mathrm{KCl}-15 \mathrm{PbCl}_{2}$ & 320 & $49 \mathrm{NaCl}-51 \mathrm{CaCl}_{2}$ & 500 \\
\hline
\end{tabular}

しい腐食作用を持つとされている ${ }^{39)}$ 。これに対して $500^{\circ} \mathrm{C}$ 以上の高温域では, $(\mathrm{Na}$ or $\mathrm{K}) \mathrm{Cl}-(\mathrm{Na} \text { or } \mathrm{K})_{2} \mathrm{SO}_{4}$ 系化合 物 (共晶点 $\left.518^{\circ} \mathrm{C}\right)$ などの塩化物 - 硫酸塩共晶系が溶融 するようになり，多くの硫酸塩を交えた溶融塩腐食が問題 となる ${ }^{38)}$ 。また，Galetz et al. はCuが Deacon 反応にお ける触媒効果以外に, 融点降下作用を持つとも指摘して いる ${ }^{40)}$ 。塩化物を含む溶融塩は保護酸化皮膜を破壊する ので, $\mathrm{SO}_{2} / \mathrm{SO}_{3}$ ガスによる金属素地の腐食も引き起こす。

融液が界面に付着または発生した場合は，融液との相 互作用により金属のイオン化反応の活性化エネルギーが 引き下げられるとともに，腐食生成物が界面から拡散除 去されるので, 腐食量は各段に増大する。電気化学的に は, 伝熱管 $\mathrm{Fe}$ のアノード反応に対する酸化剤は $\mathrm{H}_{2} \mathrm{O}$ や $\mathrm{O}_{2}$ があげられるが $\left.{ }^{41}\right), \mathrm{Cl}_{2}$ や $\mathrm{HCl}^{42}, \mathrm{CuCl}^{43)}$ も酸化剂 になりうる事例が示されている。廃棄物焼却時に生成さ れる塩化物間の溶融塩においても低融点共晶物質は生 成されるが，前述のガス腐食で界面に生成した $\mathrm{FeCl}_{2}$ や $\mathrm{FeCl}_{3}$ などの金属塩化物と $\mathrm{NaCl}$ や $\mathrm{KCl}$ との間にもさらに 低い融点の共晶物質が生じてしまうことは特筆すべき事項 となる。つまり，ガス腐食と融液による腐食反応は，相 互に作用し加速させており，他の固体燃焼条件よりも過酷 な環境下であることを示唆している。一例として，溶融塩 を用いた腐食試験事例によれば，埋没法による試験にお いて試験灰中の融液量を増やしていくと一定の死中融液 率までは腐食量が上昇するものの，その後融液率の増加 に伴って腐食量が減少するべル型と呼ばれる腐食傾向を 示した例も報告されている ${ }^{44)}$ 。この例においても，ガス 腐食と溶融塩腐食両方の相互作用の重要性が指摘されて いる。同様の評価は, 電気化学的手法で西方らによって も確認されており 45) 46)，それらによれば空隙が塩化物溶 融塩によって満たされる条件の場合は，カソード反応（酸 化剂の還元反応）が抑制されるため, 腐食電流が激減す る。さらに，薄膜の塩の場合は浸漬条件よりも腐食量が
大きくなることも併せて示されている。これらの事実は, スートブロア等による灰付着層の除去が，腐食量の増大 を引き起こす可能性を示唆しており，その影響については 実測例も示されている ${ }^{47)}$ 。また，溶融塩は界面付近の酸 素分圧を低く保ち，前述した $\mathrm{FeCl}_{2}$ から $\mathrm{Fe}_{2} \mathrm{O}_{3}$ への変化 で生成する $\mathrm{Cl}_{2}$ ガスや $\mathrm{HCl}$ ガスを内部に留める役割も果 たす。ただし，付着灰層内においては，全てが完全溶融 しているのではなく，酸化物系の大部分は固相状態で存 在する一方，低融点共晶化合部がわずかに局部溶融して いる状態であるものと考えられている ${ }^{48)}$

\section{2 灰付着層の観察・分析結果に基づく灰付着・腐食 機構の理解}

灰付着層と伝熱管界面の界面を中心とした観察および 分析は，腐食と灰付着の機構理解のために欠かすことの できない重要な手法である。しかし，前述のとおり評価 の対象が置かれていた条件・環境は千差万別であるため, その中から共通かつ普遍的な腐食・灰付着の原因を特定 することは難しい。そのため, 既往研究の報告事例と実 際に行なった分析結果を精査しながら，本質に関わる機 構を注意深く抽出する必要がある。

著者らの研究グループでは, 二つのプラントの蒸発管, 過熱蒸気管の付着灰組成について定量するとともに，樹 脂で固化した伝熱管と付着層をサンプルとして採取し付着 界面の分析を行なった。初めに，プラント A 蒸発管の付 着界面の観察・分析結果を図 4 に示す。プラント A は流 動床式ごみ焼却施設であり，灰付着層と一緒に抜管した 蒸発管の運転時の内部流体温度は約 $215^{\circ} \mathrm{C}$, 排ガス温度 は約 $700^{\circ} \mathrm{C}$ になっている。流動床式の場合, 条件によっ て流動媒体 $\left(\mathrm{SiO}_{2}\right)$ が伝熱域へ飛散することがあり，そ の場合は流動媒体による伝熱管の摩耗が生じるので, 腐 食との相乗効果で減肉がさらに加速されることがある。 なお，観察面の研磨法として水溶成分の溶出を防ぐため 

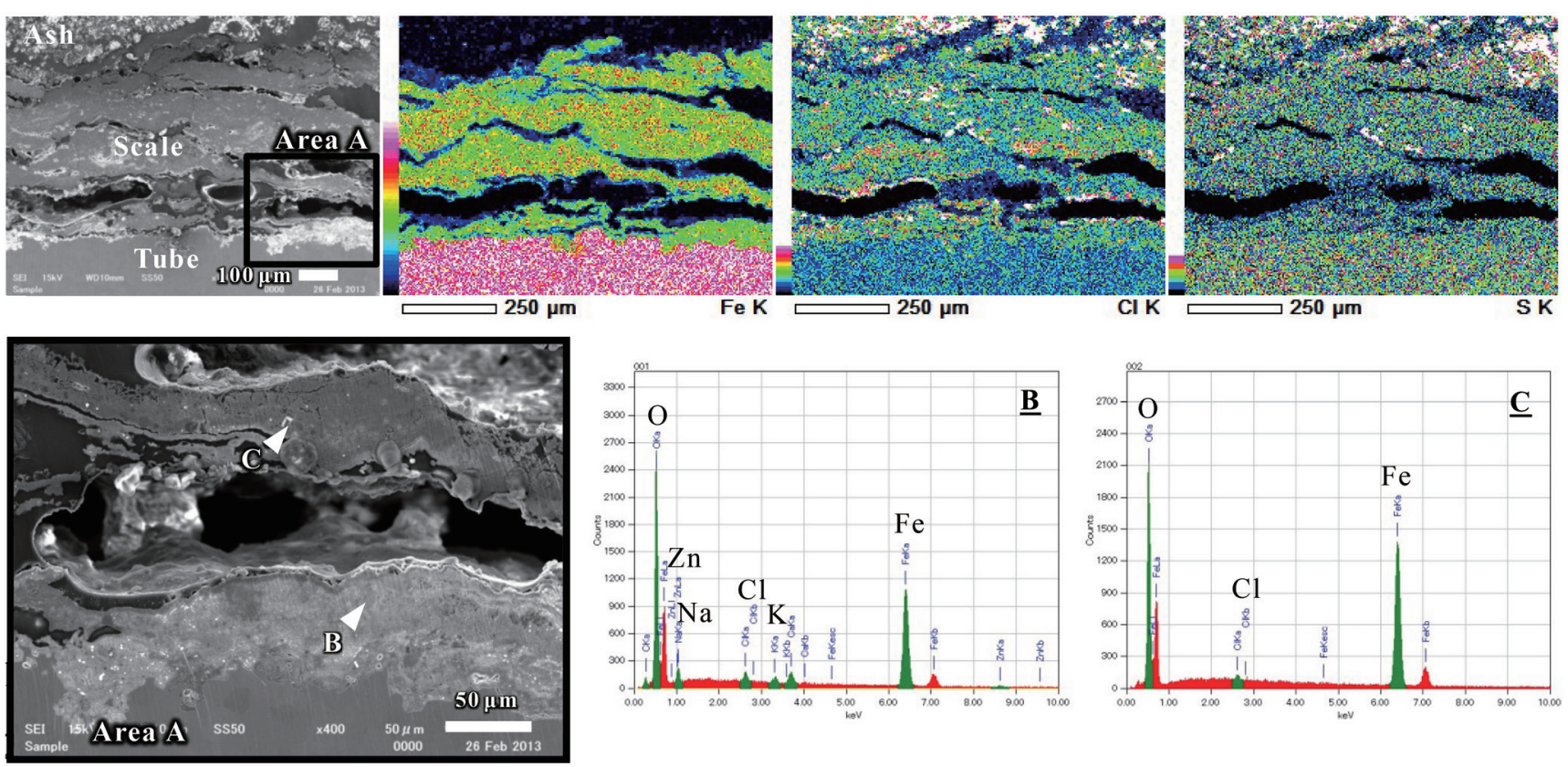

図 4 プラント A 蒸発管における付着界面の分析結果（上段：SEM 観察画像，ならびに Fe，Cl およびSのマッピング分析画像，下段： $\mathrm{A}$ 部の拡大観察画像，ならびに $\mathrm{B}, \mathrm{C}$ 点の定性分析結果)

イオンミリング法を採用した。本図より，付着灰と伝熱管 母材の間に複層の $\mathrm{Fe}$ 酸化物で構成された亀裂・空隙を 有するスケールが存在していることが分かる。また，金 属素地表面には $\mathrm{Cl}$ やアルカリ金属 (Na, K) が検出され ており，これはスケールの亀裂を通過したアルカリ塩化物 と金属素地が反応した形跡と考えることができる。また， $\mathrm{Zn}$ も同位置に存在していることから, $\mathrm{ZnCl}_{2}$ 蒸気も腐食 に関与している可能性がある。マッピング分析結果から, 外面側に分布している S 分に対して，素地とスケール間に $\mathrm{Cl}$ の分布が見られ，この近傍で塩化物が生成しうる $\mathrm{Cl}_{2}$ 分圧が維持されていることが示唆される。野口ら ${ }^{49)}$ は, $\mathrm{Ni}$ 基鋳造合金における $\mathrm{Ni}$ 塩化物の生成について酸素分 圧の低下に基づき報告しているが, 図 4のサンプルでは スケールの積層や腐食量, アルカリ金属の濃縮が野口ら の報告の対象よりも顕著であることから，それらが $\mathrm{Cl}_{2}$ の 分圧維持に影響しているものと考えられている。アルカリ 金属の $\mathrm{Cl}_{2}$ 分圧への影響としては, Grabke et al. ${ }^{50)}$ が式 (13), (14)のスケール内部の平衡 $\mathrm{Cl}_{2}$ 分圧について 10-5$10^{-8} \mathrm{~Pa}$ と推算されることを示している。

つぎに, プラント A 過熱蒸気管における灰付着界面分 析結果を図 5 に示す。内部蒸気温度は $230^{\circ} \mathrm{C}$ 程度, ガス 温度は約 $600^{\circ} \mathrm{C}$ と推定している。本図より, 蒸発管と同 様に Fe 酸化物スケールが表面に積層していることが分か る。また，各層には $\mathrm{Cl}$ の濃縮層が見られ， $\mathrm{S}$ については 蒸発管よりもわずかにスケール内部に浸透している。本分 析結果で示される塩素がスケール内部に濃縮する傾向は, 前項の腐食・付着機構で説明した理由によるものであり, Sorell ${ }^{22)}$, 図6に示す Covino et al.の結果 ${ }^{34)}$, Piispanen et al. ${ }^{51)}$, Baxter et al. ${ }^{52)}$ も同様の分析結果を示している。 アルカリ金属については, 蒸発管同様スケール内部にま で到達しており, 素地表面において粒界に沿った反応層 を観察することができる。蒸発管, 過熱器管ともにスケー ルと金属素地の界面にアルカリ金属が濃縮していることか ら, 本分析対象のガス, 灰および温度の条件では, アル カリ塩化物蒸気のスケール内部への浸透・凝縮が, 腐食 機構の重要な役割を担っているものと結論できる。

灰付着界面に打ける元素分布を評価することは, 観察 対象の各条件に対応した腐食機構を考察する上で重要と なる。そこで本研究では, SEM-EDXを用いて観察対象 を格子状に点定量分析を行ない，その定量值をマッピン グすることで腐食機構を考察した。前述と同じプラント A 過熱器管界面の定量マッピング分析結果を図 7 に示す。 本図上段左が観察画像と定量分析を行なった格子点であ り，その他は $\mathrm{Fe}, \mathrm{Na}+\mathrm{K}, \mathrm{Cl}, \mathrm{S}$ および $\mathrm{Pb}$ の定量分布 を示している。本図のとおり, 定量值 [wt％] を合わせて 表示することで，より詳細な考察が可能となる。まず, $\mathrm{Cl}$ やアルカリ金属はスケール内部の金属素地まで到達してお り, 特に $\mathrm{Na}+\mathrm{K}$ の金属素地表面左部分 (点線 a) の濃縮 エリアは $\mathrm{Fe}$ の濃縮度と合致していることから, $\mathrm{M}_{2} \mathrm{Fe}_{2} \mathrm{O}_{4}$ (M:Na or K) が生成しているものと考察できる。また, b 位置における $\mathrm{Pb}$ の濃縮エリアは, $\mathrm{Cl}$ や $\mathrm{Fe}$ の濃縮と合致 しており，前述の表 1 に示した $\mathrm{PbCl}_{2}$ と $\mathrm{FeCl}_{2}$ による共晶 物が溶融塩として存在している可能性を示唆するものであ る。 $\mathrm{Pb}$ はガス温度と比べて低温の伝熱管表面に, 塩化 物としてわずかに凝縮するものと考えることができ，実際 に断熱層となる灰付着層の外側において $\mathrm{Pb}$ 分布はほと 

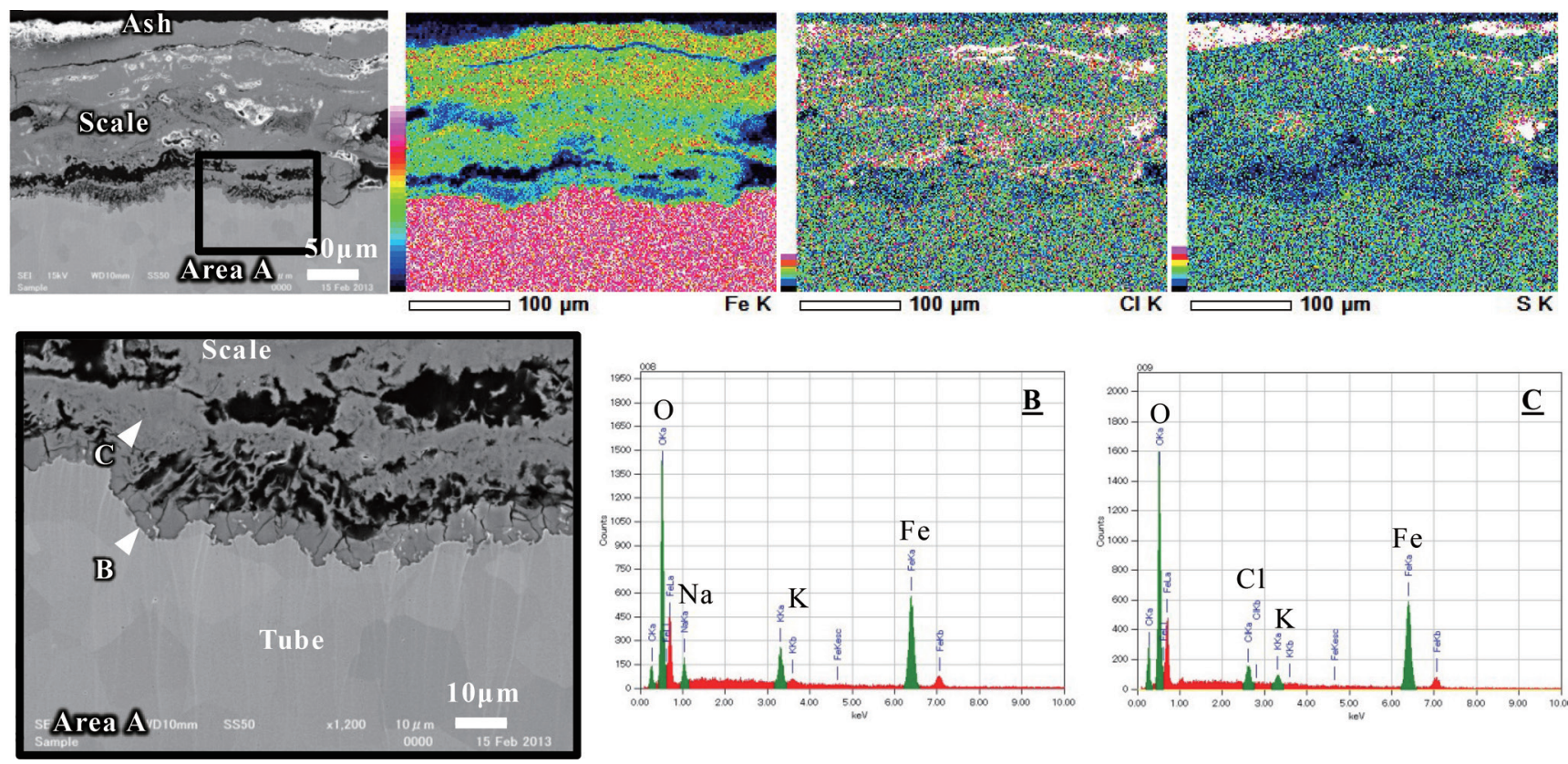

図 5 プラントA 過熱器管における付着界面の分析結果（上段:SEM 観察画像，ならびに Fe, Cl および S のマッピング分析画像，下段： $\mathrm{A}$ 部の拡大観察画像，ならびに $\mathrm{B}, \mathrm{C}$ 点の定性分析結果)
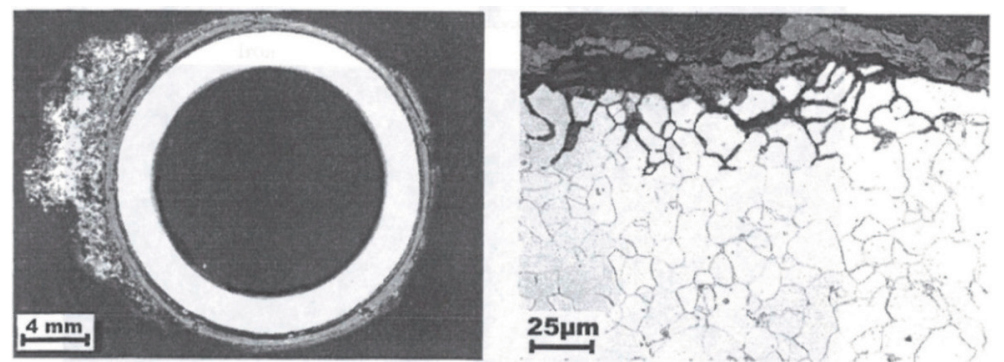

図6 左：実機伝熱管断面（6日暴露）写真, 右：界面付近写真（共に, 光学顕微鏡による） ${ }^{34)}$
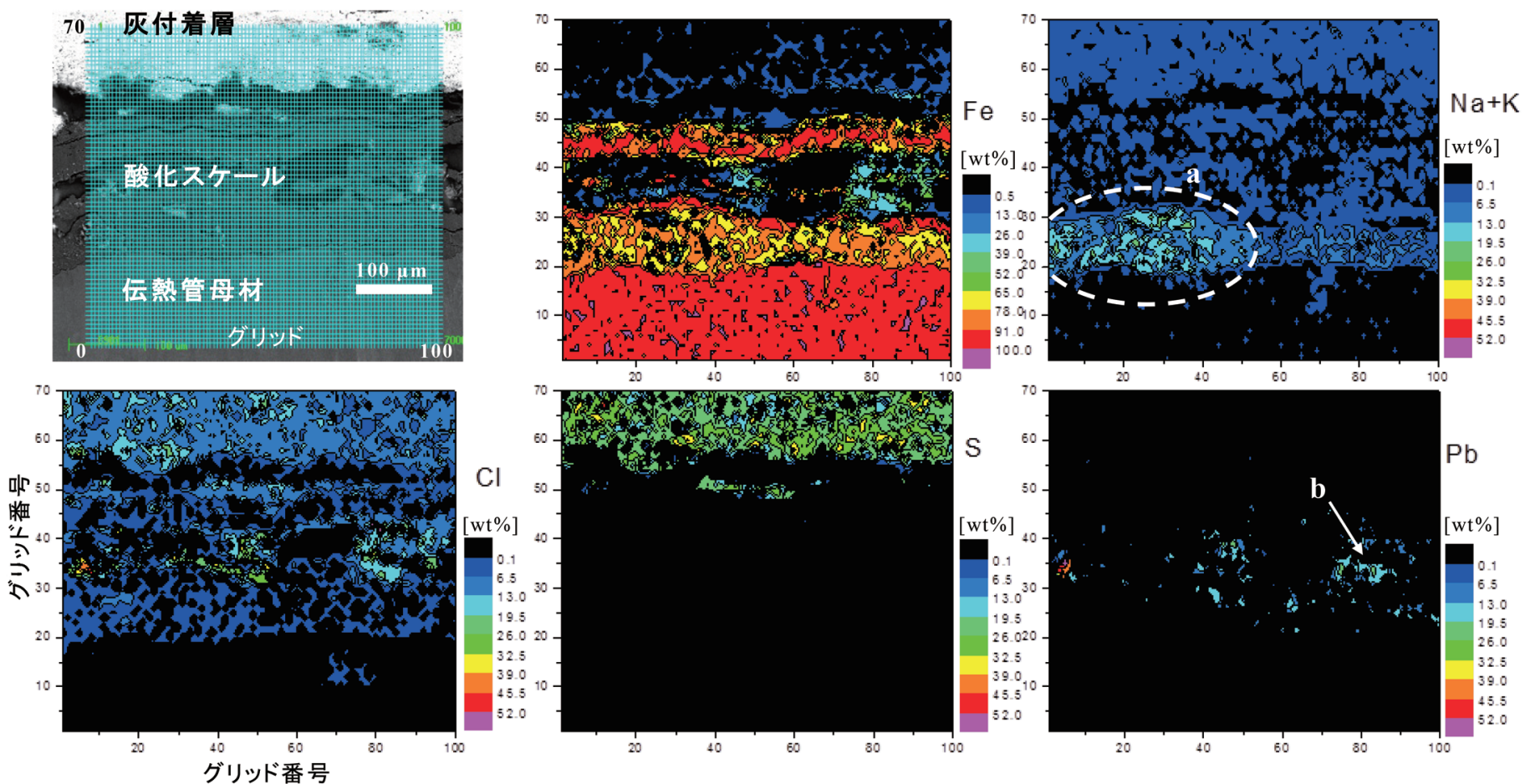

図 7 定量マッピング分析結果（プラントA，過熱器管一付着層界面）（上段左より，観察画像（測定格子付記）, Fe, Na+K 分布；下段 左より, $\mathrm{Cl}, \mathrm{S}, \mathrm{Pb}$ 分布) 
んど見られず， $550^{\circ} \mathrm{C}$ 以上では凝縮量が少なくなるという Jiao et al. ${ }^{29)}$ の結果と同様のものとなっている。さらに, 定量分布をモル比で評価することで，外層（ガス側）にア ルカリ硫酸化合物が形成されていることが明瞭に示され ている。以上のとおり, 定量マッピング分析を行なうこと でより詳細に腐食機構を考察することがきる。

次に, プラント A の灰付着層の組成について, 燃焼一 赤外線吸収法 $\left(\mathrm{SO}_{3}\right), \mathrm{ICP}$ 発光分光分析法 $\left(\mathrm{SiO}_{2}\right)$ 拈よ び燃焼ーイオンクロマトグラフ法 $(\mathrm{Cl})$ で分析した結果を 図 8 に示す。分析サンプルは, 蒸発管と過熱器管（上流 側から No.1〜3）上の灰付着層を現地で伝熱管側（内側: 伝熱管一付着物界面から約 $3 \mathrm{~mm}$ 高さまで) とガス側（外 側：約 $3 \mathrm{~mm}$ 高さからガス側全て）別々に採取したものを 用いており，伝熱管側とは主に酸化スケール層であるガス 反応層の範囲, ガス側とは主に焼却灰由来の付着物の範 囲を指す。ここで，同プラントでは蒸発管で排ガスからの 熱回収を行なってガス温度が低下した後, 次に過熱器管 で熱回収を行なっている。また，過熱器管 No.1〜 3 は, ガス流れに平行して設置された管群のうち, 最もガス (外) 側に位置した管に対しガス流れ上流（吊下げアーチ部最 下部）からガス流れに沿って順次数えた位置であり，排 ガスが過熱器管に衝突する付近（吊下げアーチ部最下部） をNo.1として，そこから下流側 $1.6 \mathrm{~m}$ 位置を No.2, さら に $1.4 \mathrm{~m}$ 位置をNo.3 とした。本図より, 付着灰中の $\mathrm{SO}_{3}$ 含有率 (S 分析值の酸化物換算) は，伝熱管側・ガス側 ともにガス流れに従って上昇していることが分かるが，こ れは前項の『3.1 灰付着・腐食の機構』ならびに前述の定 量マッピング分析における考察で記述したとおり，ガス中 または付着後に塩化物が硫酸化合物へ変化していること に起因している（式（10）拈よび（11）に示す反応）。しか
し，伝熱管側の $\mathrm{Cl}$ 含有率がガス流れに従って低下してい る反面，ガス側はわずかに上昇していることから，プラン 卜Aの環境ではガス流れ中だけではなく, 初期段階の付 着層を含む伝熱管側サンプル（図8左）では，付着後に もわずかに硫酸化合物へ変化している可能性も考えられ る。また，主に固相として伝熱管に慣性衝突する $\mathrm{SiO}_{2}$ を 含む灰粒子は，ガス流れに従って捕捉率が低下している ことが分かる。これらの傾向は既往研究結果 27) 28) 53) 54) と同様であり, 塩化物から硫酸化合物への変化は後述す る腐食抑制技術につながる機構となる。

\section{4. 灰付着・腐食の評価・対策技術}

\section{1 灰付着・腐食の評価}

\subsection{1 熱力学平衡計算}

熱力学平衡計算は様々な物質の熱力学データベースを 基に，ギブズの自由エネルギーの変化量が最小となる計 算を基本にして化学反応, Predominant（主安定領域作 図），相平衡計算などを行うもので，多くのソフトウェア が開発されている55)。そのため, 固体燃焼に伴う生成ガ スの成分・濃度や無機成分の相状態に関する平衡計算を 行なうことが可能であり, 石炭燃焼 ${ }^{56)}$ や廃棄物焼却条件 下の評価ツールとして，盛んに利用されている。例えば, Becidan et al. は耐食性向上を目的として添加された硫酸 アンモニウムとシリカの効果に関して ${ }^{57)}$, Jiao et al. は重 金属類の凝縮挙動について ${ }^{58)}$, Lindberg et al. は廃棄物 焼却灰の伝熱管上の融液量について 55), それぞれ熱力学 平衡計算を用いて評価している。

本研究では, 廃棄物焼却環境における付着灰と伝熱 管組成を用いて融液量の温度依存性に関する平衡計算を 行なった。伝熱管側の材料として，オーステナイト系ステ
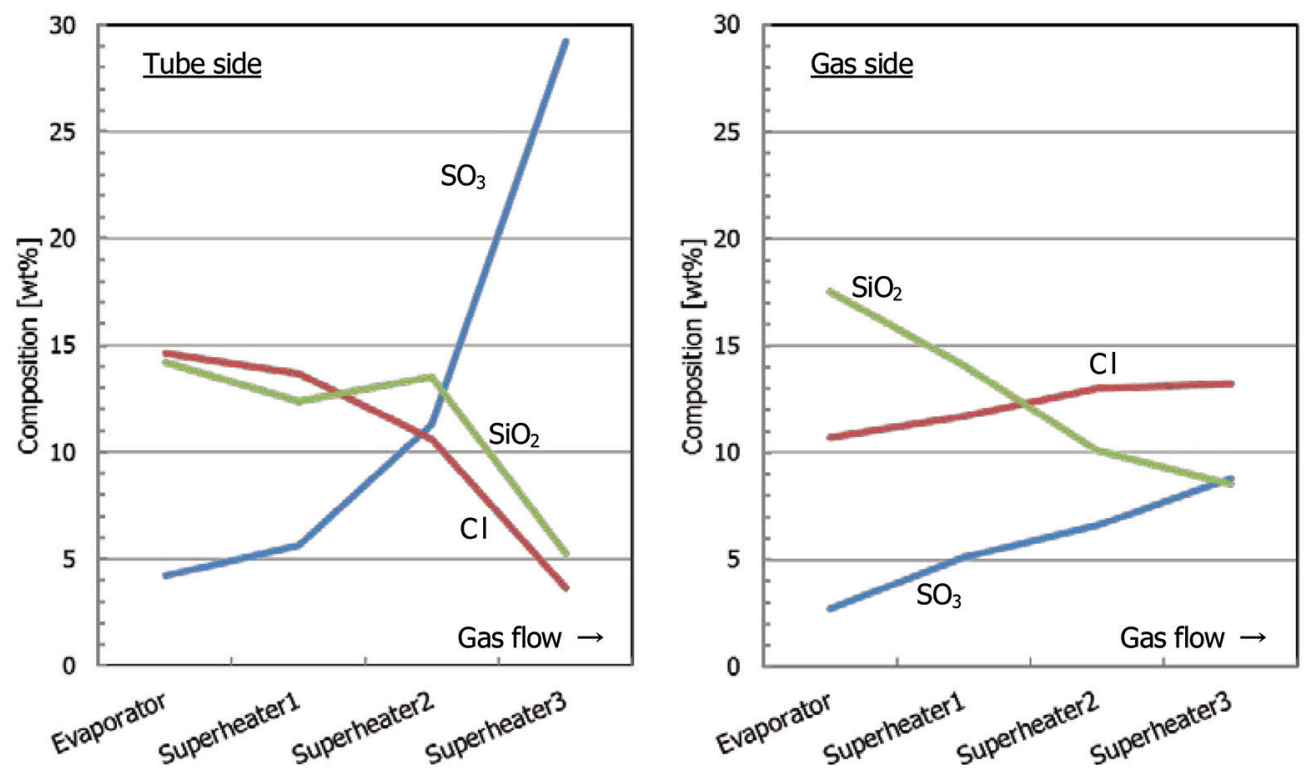

図8 付着層の定量分析結果 $\left(\mathrm{SO}_{3}, \mathrm{SiO}_{2}, \mathrm{Cl}\right)$ （左：伝熱管側，右：ガス側の付着層）※位置は蒸発管，過熱器管（上流より No.1〜3） 
ンレス材料 (SUS304)， Ni 基開発材料および Inconel625 の組成を用いて，実機ボイラのホッパーから採取した灰 組成と合わせて計算した融液量を図 9 に示す。本図よ り, SUS304 では約 $450^{\circ} \mathrm{C}$ から約 $820^{\circ} \mathrm{C}$ まで塩化物複合塩 の融液が発生していることが分かる。しかし, Alloy625 や $\mathrm{Ni}$ 基開発材料に扔ける融液生成は, 約 $5400^{\circ} \mathrm{C}$ から狭 い温度域に留まっており, 特に後者は生成温度範囲が小 さい。このように熱力学平衡計算を用いて扊付着界面に おける平衡相状態を評価する手法の有効性は，石炭然 焼環境下でも報告されており5)，廃棄物焼却環境におい
てもBorn et al.によって証明されている59)。この報告で は, $\mathrm{KCl}$ と $\mathrm{ZnCl}_{2}$ の塩と $\mathrm{Ni}$ 基合金 ( $\left.\mathrm{Ni}-\mathrm{Cr}-\mathrm{Fe}-\mathrm{Mo}-\mathrm{B}-\mathrm{Mn}\right)$, $\mathrm{O}_{2} \cdot \mathrm{Cl}_{2}$ が添加されて計算されているが，溶融塩中の合金 由来化合物として, $\mathrm{CrCl}_{2}, \mathrm{MnCl}_{2}, \mathrm{FeCl}_{2}$ が比較的高濃 度で出力されている。これは, 図 9 で示したSUS304に おいても融液の生成温度域が広くなる点と共通した傾向と して確認することができる。

\subsection{2 腐食量の評価・測定}

一般的に普及・採用されている腐食評価・試験法を表 2のとおり整理した。腐食現象の要因調査・評価手法と
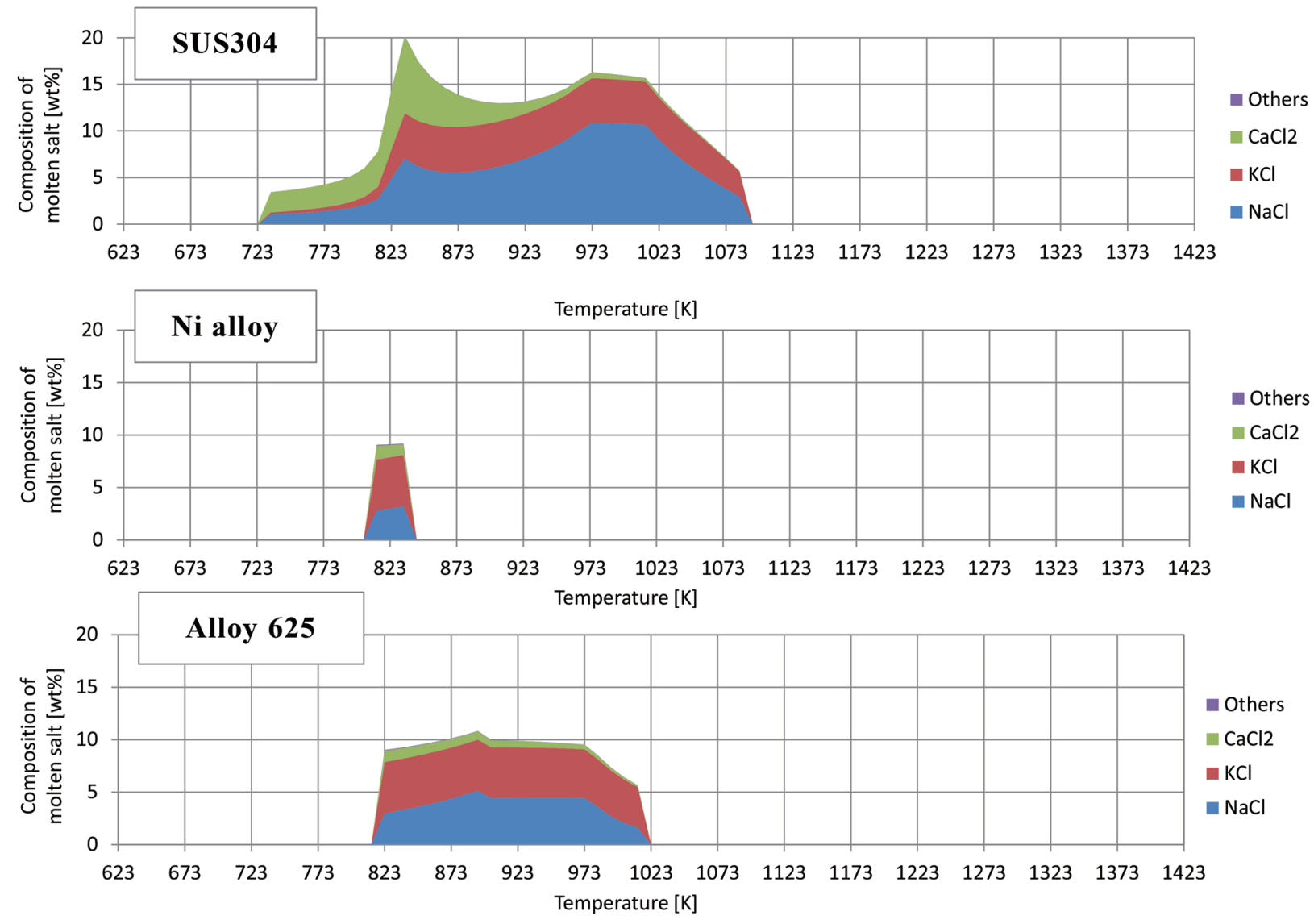

図 9 廃棄物燃焼条件における金属と付着灰間の融液量温度依存性計算結果（上段：SUS304, 中段：Ni 基開発材料, 下段：Alloy 625)

表 2 腐食評価法

\begin{tabular}{|c|c|c|c|}
\hline 実施場所 & 区 分 & & 法 \\
\hline \multirow{6}{*}{ 実験室等 } & 損傷材の観察・分析 & SEM や EPMA，XRD 等による & 観察, 界面分析, 生成物同定等 \\
\hline & \multirow{5}{*}{ 腐食試験 } & 塗布法 & JIS Z 2292:2004 \\
\hline & & 水蒸気酸化試験 & JIS Z 2287:2003 \\
\hline & & 高温腐食試験 & JIS Z 2290:2004 \\
\hline & & 高温ガス腐食試験 & JIS Z 2291:2004 \\
\hline & & 埋没法 & JIS Z 2293:2004 \\
\hline \multirow{3}{*}{$\begin{array}{l}\text { 実機 } \\
\text { (on-site) }\end{array}$} & モニタリング & 電気化学的試験 & JIS Z 2294:2004 \\
\hline & 実機挿入 & プローブ法 & $\begin{array}{l}\text { 冷却プローブに試験体を装着して, 実炉内に } \\
\text { 挿入し，定期的に減肉量を測定 }\end{array}$ \\
\hline & \multicolumn{2}{|c|}{ 実機部材の肉厚管理, 減肉量測定 } & 定検時の測定・管理 \\
\hline
\end{tabular}


しては，腐食損傷の対象が入手できる場合は下表のとお りマクロ・ミクロ観察が最も有効となるが, 高精度な考察 や要因特定が求められる場合や条件・環境から要因を推 定する場合は，各環境・条件に合った腐食試験が採用さ れる。通常，実機環境を模擬したガス成分や腐食性の塩 を金属材料と接触させて, 腐食による反応層の厚さや重 量の増減を測定することによって, 模擬環境の腐食性や 金属の耐食性を評価する方法が最も一般的に行なわれて おり，次項で示すように多くの報告事例がある。

本研究では, 表 2 の塗布法腐食試験によって腐食量を 測定するとともに, 腐食や灰付着の温度依存性や機構を 考察するために，伝熱管材料と溶融塩の濡れ性に着目し て評価を行なった。これは石炭燃焼条件下で検証された 手法 60) であり，評価対象の金属（伝熱管材料）板の上に 塩を積載し, 昇温過程の溶融塩の濡れ性について接触角 を測定して評価する静滴法に基づいている。本研究で得 られた各種 $\mathrm{Ni}$ 基合金に関する評価結果を図 10 に示す 61)。横軸の濡れ性評価については, $\mathrm{Ni}$ 基合金も含めた様々 な材料を基材（金属板）として使用し，塩化物－硫酸化 合物の混合塩 (Standard Corrosion Mixture; SCM) をそ の金属板上に積載して接触角を測定した。雲囲気ガスは 図中に示す腐食性ガスを用いた。縦軸の腐食減量につい ては，濡れ性試験と同材質の試験片板上に，同じ塩に対 し $\mathrm{Al}_{2} \mathrm{O}_{3}$ 粒子を混合 $\left(\mathrm{Al}_{2} \mathrm{O}_{3}\right.$ 混合比により Ash1 と Ash2 を準備）した灰を塗布する塗布法試験により計測した。 雲囲気ガスも濡れ性試験と同様の腐食性ガスを用いた。 図 10 より接触角が高い材料を用いることで，腐食量を抑 制できることが分かる。つまり，溶融塩と金属素地の接
触面積で腐食量に差が生じることを意味している。このこ とから, 溶融塩含有率が低い(Ash2) と接触角の影響が 比較的小さく低接触角側で腐食量増分が鈍化することに なり, 一方, 溶融塩含有率が高い場合 (Ash1) は接触角 と腐食量との関係が線形に近づく結果となっている。

\section{2 灰付着・腐食の対策技術}

\subsection{1 添加剂}

廃棄物に意図的に物質を添加して腐食・灰付着抑制を 目指した既往研究は多い。Wang et al. は添加剂の効果 を(1)化学的吸収·相互作用, (2)物理的吸収, (3)希釈. 不活性元素の増大, (4)抑制・粉化効果の4つに分類しレ ビューを行なった ${ }^{62}$ 。本論でこれまでに記述したとおり， 塩化物を硫酸化合物へ変化させることで基本的にその融 点は上昇する傾向にあることから，腐食や灰付着を抑制 できる可能性がある。Viklund et al. は硫酸アンモニウム を添加して $\mathrm{SO}_{3}$ ガス濃度を増やすことで, 腐食量を低減 できることを示しており ${ }^{63)}$, 付着物中の塩素濃度の減少 と硫黄濃度の上昇を例示している。Becidan et al. は硫酸 アンモニウムとシリカの添加による腐食抑制効果につい て, 熱力学平衡計算によって証明している ${ }^{57)}$ 。 Krause et al. は下水スラッジを添加することで, $\mathrm{SO}_{2}$ ガス濃度を上昇 させて，腐食量を低減できることを示している ${ }^{64)}$ また Johansson et al. はカオリナイト鉱物の添加や他のバイオマ 又燃料との混焼で, 腐食量を低減できることを実機で確 認している ${ }^{65)}$ 。以上のように，それらの効果は明確であ るが，研究開発途上のものが多く，また，添加剤の導入 と灰処理量の増大によってコスト高も課題になっている。

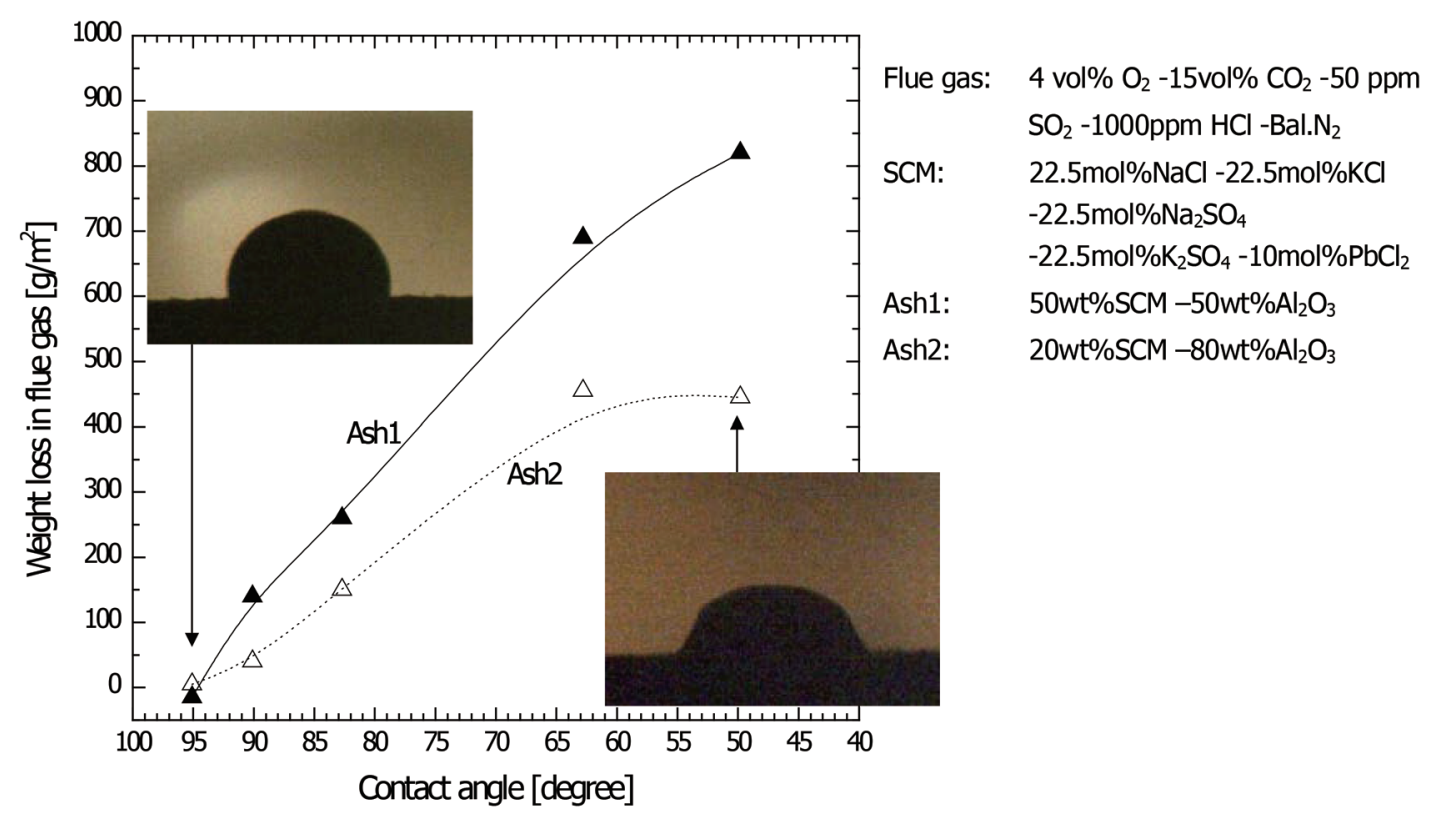

図 10 溶融塩に対する濡机性（接触角）と腐食量（塗布法）の関係（温度：500 $\mathrm{C}$, 雾囲気：腐食性ガス, 基板： $\mathrm{Ni}$ 基合金，灰：接触 角測定時は 100\%SCM，腐食量測定時は Ash1 と Ash2) 


\subsection{2 伝熱管材料の変更および表面改質技術の適用}

腐食性ガスや付着灰と接する伝熱管側からの腐食低減 に関するアプローチに関しては, 表 3 のおり多くの報告 事例がある。伝熱管の材質（肉盛溶接や溶射も含む）は 使用されている環境に依存し，特に蒸気温度が腐食量に 影響することから，前述した加速的腐食が開始される温 度 $\left(400 \sim 450^{\circ} \mathrm{C}\right)$ を境に材質の選定方針は区別される。 表 3 のデー夕は主に高蒸気条件における耐食性評価を目 的として研究された知見であり，一般的には $350^{\circ} \mathrm{C}$ 以下の メタル温度の条件ではコストの観点から炭素鋼が用いら れることが多い。表3のと扔り，合金中の $\mathrm{Ni}$ が耐食性に 寄与する効果は数多くの事例で認められており, 従来 $\mathrm{Ni}$ がベースとして材料開発が進められている。また，表面 改質材料（肉盛溶接や溶射）の成分設計においては耐食 性に絞って検討できることから， $\mathrm{Ni}$ 基合金の評価事例が 多く，その他の成分として $\mathrm{Cr}$ や $\mathrm{Mo}$ 等の効能も着眼され ている。このことは別に研究・構築された伝熱管の腐食 減肉量の予測式，例えば NEDO プロジェクトでは式 (17) が提案されているが 79 )，同式では合金中の $\mathrm{Cr} ， \mathrm{Ni}$ およ
び Mo 量が一定の条件下で腐食量低減に寄与することを 表している。

$$
\begin{aligned}
W=10-33.8 & \cdot[\mathrm{Tg}]^{5.65} \cdot[\mathrm{Tm}]^{4.86} \cdot[\mathrm{HCl}]^{0.576} \\
& \cdot[\mathrm{Cl}]^{0.419} \cdot[\mathrm{Cr}+\mathrm{Ni}+\mathrm{Mo}]^{0.391} \cdot \text { Time }
\end{aligned}
$$

$W$ : 腐食量, $\operatorname{Tg}$ : ガス温度 $\left[{ }^{\circ} \mathrm{C}\right], \mathrm{Tm}$ : メタル温度 $\left[{ }^{\circ} \mathrm{C}\right]$, $\mathrm{HCl}$ ：燃焼ガス中の $\mathrm{HCl}$ 濃度 $[\mathrm{ppm}], \mathrm{Cl}$ : 付着灰中の $\mathrm{Cl}$ 濃度 $[\mathrm{wt} \%], \mathrm{Cr}+\mathrm{Ni}+\mathrm{Mo}$ ：材料中の $\mathrm{Cr}, \mathrm{Ni}$ 及び $\mathrm{Mo}$ 量の合計 [wt\%]，Time：時間 [hr]

前述した $\mathrm{Cl}$ 系ガスによる金属元素の塩化物に関するギ ブズ自由エネルギー変化量や蒸気圧等は, 表 4 のとおり 整理できる。 $\mathrm{NiCl}_{2}$ は $\mathrm{FeCl}_{2}$ と比較すれば揮発性が小さ く, 融点と $\mathrm{T}_{4}$ 温度（対象となる塩化物の蒸気圧が 10.13 $\mathrm{Pa}\left(10^{-4} \mathrm{~atm}\right)$ のときの温度）がともに高いので, 前述し た加速的な腐食は進み難い。

$\mathrm{Cr}$ は $\mathrm{O}_{2}$ 存在下で安定なスピネル酸化物を形成するが, $\mathrm{Cl}$ 系ガスと反応して表4のとおり $\mathrm{CrCl}_{2}$ を生成するため, $\mathrm{Cr}$ 含有率を単純に増加させることによる耐食性への寄与 は明確ではない。また，Cr はアルカリ塩化物，重金属塩 化物と式（13）や式（18）のとおり反応するが，次式につい

\begin{tabular}{|c|c|c|c|c|}
\hline 分類 & 管または表面改質材の組成 & 件 & 結 & 文献 \\
\hline \multirow{4}{*}{$\begin{array}{l}\text { 伝 } \\
\text { 熱 } \\
\text { 管 } \\
\text { 材 } \\
\text { 料 }\end{array}$} & $\begin{array}{l}\text { 40Ni-20Cr-other } \\
\text { other: Mo, Si, Al, Cu, Ti }\end{array}$ & $\begin{array}{l}\text { 模擬ガス, 塩化物 - 硫酸塩混合 } \\
\text { 灰の塗布法 }\end{array}$ & $\begin{array}{l}\text { 40Ni-20Cr 系材料における添加元素の耐 } \\
\text { 食性向上効果を評価。 }\end{array}$ & 66) \\
\hline & 炭素鋼から高 $\mathrm{Cr}(25 \mathrm{Cr})$ 鋼 & $\begin{array}{l}\text { 実機にて腐食プローブを使用 (10 } \\
\text { 日間) }\end{array}$ & Cr 含有率に比例して耐食性が向上。 & $67)$ \\
\hline & $\begin{array}{l}\text { Superni75 (20Cr-3Fe-bal.Ni) } \\
\text { Superfer800H (32Ni-21Cr-1.5Mn- } \\
\text { bal.Fe) }\end{array}$ & $\begin{array}{l}\mathrm{Na}_{2} \mathrm{SO}_{4}-25 \% \mathrm{NaCl} \\
\text { 大気中, } 800^{\circ} \mathrm{C}\end{array}$ & $\begin{array}{l}\text { Superni75 が Superfer800H を上回る耐食 } \\
\text { 性を示した。 }\end{array}$ & 68) \\
\hline & 低合金鋼から $\mathrm{Ni}$ 基合金 & $\begin{array}{l}\text { 実機にて蒸気温度 } 460 \sim 540^{\circ} \mathrm{C} \text {, } \\
738 \text { 時間 }\end{array}$ & $\begin{array}{l}\text { Alloy28 (30Ni-27Cr-3.3Mo-1.6Mn-bal.Fe) } \\
\text { が最も高い耐食性を示した。Cr や Moの } \\
\text { 有効性を確認。 }\end{array}$ & 69) \\
\hline \multirow{4}{*}{$\begin{array}{l}\text { 肉 } \\
\text { 盛 } \\
\text { 溶 } \\
\text { 接 }\end{array}$} & Alloy 625 & $\begin{array}{l}\text { 実機蒸発管 (蒸気温度：330ㅇ), } \\
\text { 二年間 }\end{array}$ & 10 年以上の耐久性を示す。 & 70) \\
\hline & $\begin{array}{l}\text { オーステナイト系ステンレス, } 625 \\
\text { 等 }\end{array}$ & $\begin{array}{l}\text { 流 動層, } \mathrm{HCl} \text { ガ ス, } 316{ }^{\circ} \mathrm{C}, 20 \\
\text { 時間 }\end{array}$ & $\begin{array}{l}\text { Alloy140（45WC-45Ni-6.5Cr-2Si-1.5B） が } \\
\text { 高い耐食・耐摩耗性を有する。 }\end{array}$ & 71) \\
\hline & Alloy $625,59,650,22,310$ & 実機 CFB, 蒸発管, 7727 時間 & Alloy625, 22 が高い耐食性を示した。 & 72) \\
\hline & Alloy $625,622,31,309,310$ & 塗布法, $600^{\circ} \mathrm{C}, 1008$ 時間 & $\begin{array}{l}\text { Allloy31 が } 625 \text { と同等の高い耐食性を示 } \\
\text { した。 }\end{array}$ & 73) \\
\hline \multirow{5}{*}{$\begin{array}{l}\text { 溶 } \\
\text { 射 } \\
\text { 法 }\end{array}$} & Alloy622, Ni-Cr-Co, Ni-Cr-Fe-Al-Y & $\begin{array}{l}\text { 実機プローブ, ガス温度 } 870^{\circ} \mathrm{C}, \\
\text { メタル温度 } 316^{\circ} \mathrm{C} \text { 以下 }\end{array}$ & $\begin{array}{l}\text { Alloy622 が高い耐食性を示したものの, } \\
\text { 母材に対しての密着力は小。 }\end{array}$ & 74) \\
\hline & $\mathrm{Ni}$ 基合金 $(\mathrm{APS}, \mathrm{HVOF})$ & $\begin{array}{l}\text { 埋没法, } 350^{\circ} \mathrm{C}, \\
\mathrm{KCl}-\mathrm{ZnCl}_{2}-\mathrm{PbCl}_{2} \text { 塩 }\end{array}$ & $\begin{array}{l}\text { HVOF 溶射による Alloy625 が最も高い耐 } \\
\text { 食性で Si の添加が有効。 }\end{array}$ & 75) \\
\hline & 2 層 $80 \mathrm{Ni}-20 \mathrm{Cr} / \mathrm{Al}$ (ガス) & 実機, メタル温度 $230 \sim 300^{\circ} \mathrm{C}$ & $\begin{array}{l}\text { アンダーに } \mathrm{Ni} \text { 基合金, トップに } \mathrm{Al} \text { 層, } 3 \\
\text { 年以上の耐用年数。 }\end{array}$ & 76) \\
\hline & $50 \mathrm{Ni}-50 \mathrm{Cr}$ (Detonation) & 実機, 蒸発管 & 7 年の耐用年数を確認。 & 77) \\
\hline & $\mathrm{Ni}$ 基合金（HVOF） & $400^{\circ} \mathrm{C}, \mathrm{KCl}-\mathrm{ZnCl}_{2}$ 塩, 360 時間 & Diamalloy1005 が高い耐食性 & 78) \\
\hline
\end{tabular}

表 3 伝熱管側の耐食性評価に関する報告事例 
表 4 金属塩化物 $\left(\mathrm{MCl}_{2}\right)$ の物性 ${ }^{80)}$

\begin{tabular}{ccccc}
\hline Chloride & $\mathrm{T}_{\mathrm{m}}\left[{ }^{\circ} \mathrm{C}\right]$ & $\mathrm{T}_{4}\left[{ }^{\circ} \mathrm{C}\right]$ & $\Delta \mathrm{G}$ at $550^{\circ} \mathrm{C}[\mathrm{kJ} / \mathrm{mol}] \mathrm{M}+\mathrm{Cl}_{2}=\mathrm{MCl}_{2}$ & Partial Pressure of $\mathrm{MCl}_{2}$ at $550^{\circ} \mathrm{C}[\mathrm{Pa}]$ \\
\hline $\mathrm{FeCl}_{2}$ & 303 & 536 & -238 & 21 \\
$\mathrm{NiCl}_{2}$ & 1030 & 607 & -181 & 1.3 \\
$\mathrm{CrCl}_{2}$ & 820 & 741 & -292 & $2.0 \times 10^{-2}$ \\
\hline
\end{tabular}

ては本研究の腐食試験でも確認できている ${ }^{81)}$

$$
\begin{aligned}
2 \mathrm{PbCl}_{2}(\mathrm{l})+ & \mathrm{Cr}_{2} \mathrm{O}_{3}(\mathrm{~s})+5 / 2 \mathrm{O}_{2}(\mathrm{~g}) \\
& \rightarrow 2 \mathrm{PbCrO}_{4}(\mathrm{~s})+2 \mathrm{Cl}_{2}(\mathrm{~g})
\end{aligned}
$$

さらに, $\mathrm{Cr}_{2} \mathrm{O}_{3}$ はオキシクロリネーション反応により揮 発性の高い $\mathrm{CrO}_{2} \mathrm{Cl}_{2}$ に変化して保護皮膜が劣化する可能 性 ${ }^{39)}$ や, 下式の過不働態溶解が起こる可能性も指摘され ているが46)，粒界の Cr 欠乏相または濃縮相に沿って腐 食が進展する報告もあり 21 ，耐食性や腐食機構には未だ 不明な点が残されている。

$$
\mathrm{Cr}_{2} \mathrm{O}_{3}+5 \mathrm{O}^{2-} \rightarrow 2 \mathrm{CrO}_{4}^{2-}+6 \mathrm{e}-
$$

\section{5. まとめ}

本論では，著者らが環境省環境研究総合推進費補助 金で実施した実機調查，各種試験および文献調査の結 果を元に，灰付着と腐食の機構に関して整理・評価した。 廃棄物燃焼環境は, 温度, ガス・灰分の成分の変動が 大きく，塩素系ガスや水蒸気を多く含んだ厳しい腐食䨌 囲気であるため, 低い蒸気条件での運用が必要となるう えに，定量的な評価が困難となる場合が多い。また，本 来の廃棄物処理の目的が優先されることから，ボイラの 高効率運用は契緊の課題とならない傾向にある。しか し，近年の目覚しい材料開発やプラントデザインの進展に より, 一定のポテンシャルを有する課題解決策が提案され つつある。

前述の著者らの研究では, 本論の知見をベースとして 溶射法を用いた伝熱管表面改質による死付着・腐食低減 技術の研究開発を実施してきたが，上記の課題解決のた めにはさらなる発展的研究と精度の高い定量的評価手法 の構築が必要となる。また，他の対策との複合利用によ る費用対効果の高い総合的解決策への挑戦も求められ る。

廃棄物焼却プラントにおける灰付着や腐食機構は複雑 で多様であるため，本論においても統一した見解を得ら れていない。しかし，バイオマスエネルギー利用促進の 機運が高まっている現状において, 上記の課題解決に向 けた今後の国内の様々な取り組みにおいて，本論で整理 した知見が少しでも広く役に立てれば幸いである。

\section{謝 辞}

本研究は, 環境省環境研究総合推進費「伝熱管表面改 質技術による廃衰物焼却炉発電効率の革新的向上」の一 環として平成 24 年度から 26 年度に行われた。ここに記
して関係各位に謝意を表する。

\section{文 献: References}

1) J. Jpn. Inst. Energy, 94(9), 968-971 (2015)：日エネ誌, 94(9), 968-971 (2015)

2) Ministry of Agriculture, Forestry and Fisheries, http://www.maff.go.jp/kinki/kikaku/baiomass/pdf/ gaiyou_091218.pdf (Last accessed July 21, 2016) : 農 林水産省 HP, http://www.maff.go.jp/kinki/kikaku/ baiomass/pdf/gaiyou_091218.pdf（最終アクセス日： 2016.7.21)

3) Ministry of the Environment, http://www.env.go.jp/ recycle/report/h24-02/01.pdf (Last accessed July 21, 2016) : 環境省 HP, http://www.env.go.jp/recycle/ report/h24-02/01.pdf (最終アクセス日 : 2016.7.21)

4) New Energy and Industrial Technology Development Organization, http://www.nedo.go.jp/ content/100087257.pdf (Last accessed July 21, 2016)：国立研究開発法人新エネルギー・産業技術総 合開発機構 (NEDO) HP, http://www.nedo.go.jp/ content/100087257.pdf（最終アクセス日：2016.7.21)

5) Naruse, I.; Yoshiie, R.; Matsuura, M.; Ueki, Y.; Naganuma, H.; Ito, T., J. Chem. Eng. Jpn., 43(8), 872$879(2010)$

6) Naganuma, H.; Ito, T.; Satake, H.; Matsuura, M.; Ueki, Y.; Yoshiie, R.; Naruse, I., Fuel Process. Technol., 105, 77-81 (2013)

7) Final report of the Environmental Research and Technology Development Fund (ERTDF, 3K123011) from Ministry of the Environment: 平成 26 年度環 境研究総合推進費補助金研究事業総合研究報告書, 伝熱管表面改質技術による廃棄物焼却炉発電効率 の革新的向上 (3K123011), https://www.env.go.jp/ policy/kenkyu/suishin/kadai/syuryo_report/h26/ pdf/3K123011.pdf (最終アクセス日 : 2016.7.21)

8) Barnes, I., IEA Clean Coal Centre Report, CCC/253 (2015)

9) Krause, H. H.; Vaughan, D. A.; Cover, P. W.: Boyd, W. K.; Olexsey, R. A., Transactions of the ASME Journal of Engineering for Power, 101(4), 592-597 (1979)

10) Kakizaki, T., Kankyo Gijutsu, 20(11), 688-693 (1991): 柿崎孝，環境技術，20(11), 688-693, (1991) 
11) Matsuto, T.; Ishii, S., Haikibutsu Shigen Junkan Gakkaishi, 22(6), 382-395 (2011): 松藤敏彦, 石井翔太, 廃棄物資源循環学会論文誌, 22(6), 382-395 (2011)

12) Capablo, J.; Jensen, P. A.; Pedersen, K. H.; Hjuler, K.; Nikolaisen, L.; Backman, R.; Frandsen, F. J., Energy \& Fuels, 23(3/4), (2009)

13) Pederson, A. J.; Frandsen, F. J.; Riber, C.; Astrup, T.; Thomsen, S. N.; Lundtorp, K; Mortensen, L, Energy \& Fuels, 23, 3475-3489 (2009)

14) Ministry of the Environment, http://www.env.go.jp/ recycle/circul/recycle.html (Last accessed July 21, 2016)：環 境 省 HP, http://www.env.go.jp/recycle/ circul/recycle.html (最終アクセス日 : 2016.7.21)

15) Nishitani, T.; Yamauchi, T.; Nagayama, T., Haikibutsu Shigen Junkan Gakkaishi, 21(6), 347-357 (2010) : 西谷隆 司, 山内淳行, 永山貴志, 廃棄物資源循環学会論文誌, 21(6), 347-357 (2010)

16) Toshiki, K.; Ryu, T., MACRO REVIEW, 20(1), 2940 (2007)：戸敷浩介，劉庭秀，MACRO REVIEW, 20(1), 29-40 (2007)

17) Pedersen, A. J.; Lith, S. C. V.; Frandsen, F. J.; Steinsen, S. D.; Holgersen, L. B.; Fuel Process. Technol., 91, 1062-1072 (2010)

18) Bankiewicz, D., Abo Akademi Academic Dissertation, Report 12-03 (2012)

19) Nielsen, H. P.; Frandsen, F. J.; Dam-Johansen, K.; Baxter, L. L., Prog. Energy Combust. Sci., 26, 283-298 (2000)

20) Kawahara, Y., Zairyo-to-kankyo, 54, 183-194 (2005): 川原雄三, Zairyo-to-kankyo, 54, 183-194 (2005)

21) Okoro, S. C.; Montgomery, M.; Frandsen, F. J.; Pantleon, K., Energy \& Fuels, 29, 5802-5815 (2015)

22) Sorell, G., Mater. High Temp., 14(3), 137-150 (1997)

23) Mayer, P.; Manolescu, A. V., Corrosion, 36(7), 369-373 (1980)

24) Bryers, R. W., Prog. Energy Combustion Sci., 22, 29120 (1996)

25) Aho, M.; Silvennoinen, J., Fuel, 83, 1299-1305 (2004)

26) Deuerling, C.; Maguhn, J.; Nordsieck, H.; Benker, B.; Zimmermann, R.; Warnecke, R., Heat Transfer Eng., 30(10-11), 822-831 (2009)

27) Montgomery, M.; Larsen, O. H.; Corrosion/2001, No.01184 (2001)

28) Reichelt, J.; Pfrang-Stotz, G.; Bergfeldt, B.; Seifert, H.; Knapp, P., Waste Management, 33, 43-51 (2013)

29) Jiao, F.; Zhang, L.; Yamada, N.; Sato, A.; Ninomiya, Y., Fuel Process. Technol., 105, 181-187 (2013)

30) Jones, F.; Niklasson, F.; Lindberg, D.; Hupa, M.,
Energy \& Fuel, 27, 4999-5007 (2013)

31) Karlsson, S.; Josson, T.; Hall, J.; Svensson, J. E.; Liske, J., Energy \& Fuel, 28, 3102-3109 (2014)

32) Perez, F. J.; Hierro, M. P.; Nieto, J., Mater. Corros., 59(7), 566-572 (2008)

33) Dunnu, G.; Maier, J.; Scheffknecht, G., Fuel, 89, 1534$1540(2010)$

34) Covino, B. S.; Russell, J. H.; Cramer, S. D.; Holcomb, G. R.; Bullard, S. J.; Moroz, M. Z.; Matthes, S. A.; White, M. L., Corrosion, 03718 (2003)

35) Pettersson, A.; Niklasson, F.; Moradian, F., Fuel Process. Technol., 105, 28-36 (2013)

36) Salmenoja, K.; Mäkelä, K; Hupa, M.; Backman, R., J. Inst. Energy, 69(480), 155-162 (1996)

37) Lai, G. Y., High-Temperature Corrosion And Materials Applications, ASM International, 335-358 (2007)

38) Rademakers, P.; Hesseling, W.; Wetering, J. V., TNO report, 102/01333/ RAD (2002)

39) Yoshiba, M., Haikibutsu Shigen Junkan Gakkaishi, 13(1), 38-46 (2002) : 吉葉正行, 廃棄物学会誌, 13(1), 38-46 (2002)

40) Galetz, M. C.; Bauer, J. T.; Schutze, M.; Noguchi, M.; Takatoh, C.; Cho, H., Mater. Corros., 65(8), (2014)

41) Nishikata, A.; Numata, H.; Tsuru, T., J. Mater. Sci. Eng., A146, 15-31 (1991)

42) Sharp, W. B. A., Todays science and technology, DOE Industrial Technologies Program, ORNL/TM2011/399 (2010)

43) Matsumoto, K.; Matsunaga, Y., Nakagawa, K., Zairyo-to-kankyo, 46, 16-23 (1997)：松本晃一，松永康 夫, 中川精和, Zairyo-to-kankyo, 46, 16-23 (1997)

44) Kawahara, Y.; Kira, M., Zairyo-to-Kankyo, 46, 8-15 (1997)：川原雄三，吉良雅治，Zairyo-to-Kankyo，46, 8-15 (1997)

45) Nishikata, A.; Shibahashi, T.; Tsuru, T.; Kobayashi, S.; Urabe, T., Nippon Kinzoku Gakkaishi, 63(7), 843-850 (1999) : 西方篤, 柴橋威光, 水流徹, 小林重夫, 占部 武生, 日本金属学会誌, 63(7), 843-850 (1999)

46) Zhang, G.; Nishikata, A.; Tsuru, T., Nippon Kinzoku Gakkaishi, 61(7), 587 (1997) : 張弓, 西方篤, 水流徹, 日本金属学会誌, 61(7), 587 (1997)

47) Noguchi, M., 180th Fushoku Boshoku symposium, 57-66 (2014) : 野口学, 第 180 回腐食防食シンポジウム 資料，57-66 (2014)

48) Yoshiba, M., Materia Japan, 38(3), 203-211 (1999) : 吉 葉正行，まてりあ, 38(3), 203-211 (1999)

49) Noguchi, M.; Matsuoka, K.; Fujimura, H.; Sawada, Y.; 
Ueda, S., Zairyo-to-Kankyo, 51(2), 75-80 (2002): 野口学, 松岡慶, 藤村宏幸, 澤田義行, 植田茂紀, Zairyo-toKankyo, 51(2), 75-80 (2002)

50) Grabke, H. J.; Reese, E.; Spiegel, M., Corros. Sci., 37, 1023-1043 (1995)

51) Piispanen, M. H.; Tiainen, M. S.; Laitinen, R., Energy \& Fuels, 23, 3446-3450 (2009)

52) Baxter, L. L.; Miles, Jr. T. R.; Jenkins, B. M.; Milne, T.; Dayton, D.; Bryers, R. W.; Oden, L. L., Fuel Process. Technol., 54, 47-78 (1998)

53) Zevenhoven-Onderwater, M., Ash forming matter in biomass fuels, Abo Akademi academic dissertation, Report 01-03 (2001)

54) Chen, G.; Zhang, N.; Ma, W.; Rotter, V. S.; Wang, Y., Fuel, 140, 317-327 (2015)

55) Lindberg, D.; Backman, R.; Chartrand, P.; Hupa, M., Fuel Process. Technol., 105, 129-141 (2013)

56) Akiyama, K.; Pak, H.; Takubo, Y.; Tada, T.; Ueki, Y.; Yoshiie, R.; Naruse, I., Fuel Process. Technol., 92, 13551361 (2011)

57) Becidan, M.; Sørum, L.; Frandsen, F. J.; Pedersen, A. J., Fuel, 88, 595-604 (2009)

58) Jiao, F.; Zhang, L.; Song, W.; Meng, Y.; Yamada, N.; Sato, A.; Ninomiya, Y., Proc. Combust. Inst., 34(2), 2821-2829 (2013)

59) Born, M.; Korb, J.; Rafaja, D.; Dopita, M.; Schulein, R. W., Mater. Corros., 58(9), 653-660 (2007)

60) Naganuma, H.; Ikeda, N.; Kawai, T.; Takuwa, T.; Ito, T.; Igarashi, Y.; Yoshiie, R.; Naruse, I., Proc. Combust. Inst., 32, 2709-2716 (2009)

61) Chen, J.; Ninomiya, Y.; Naganuma, H.; Sasaki, Y.; Noguchi, M.; Cho, H.; Ueki, Y.; Yoshiie, R.; Naruse, I., Fuel Process. Technol., 141, 216-224 (2016)

62) Wang, L.; Hustad, J. E.; Skreiberg, O.; Skjevrak, G.; Gronli, M., Energy Procedia, 20, 20-29 (2012)

63) Viklund, P.; Pettersson, R.; Hjornhede, A.; Henderson, P.; Sjovall, P., Corros. Eng., Sci. Technol., 44(3), 234-240 (2009)

64) Krause, H. H.; Cover, P. W.; Berry, W. E.; Olexsey, R. A., ASME Journal, No.79-WA/CD-2 (1979)

65) Johansson, L. S.; Leckner, B.; Tullin, C.; Amand, L. E.; Davidsson, K., Energy \& Fuels, 22(5), 3005-3015 (2008)
66) Otsuka, N.; Nishiyama, Y.; Miyahara, O.; Matsuo, T., Corrosion, 07345 (2007)

67) Persson, K.; Broström, M.; Carlsson, J.; Nordin, A.; Backman, R., Fuel Process. Technol., 88, 1178-1182 (2007)

68) Sidhu, T. S.; Malik, A.; Prakash, S.; Agrawal, R. D., Int. J. Phys. Sci., 1(1), 027-033 (2006)

69) Andersson, P.; Norell, M., Mater. Corros., 56(7), 449$458(2005)$

70) Kawahara, Y.; Orita, N.; Takahashi, K.; Nakagawa, H., Tetsu to Hagane, 87(8), (2001): 川原雄三, 折田寛彦, 高橋和義，中川裕二，鉄と鋼, 87(8), 2001

71) Lai, G.; Lienden, C. V.; Hou, P. Y., Corrosion 2001, 01161, 2001

72) Pettersson, R. F. A.; Storesund, J.; Nordling, M., Corros. Eng., Sci. Technol., 44(3), 218-226 (2009)

73) Paul, L.; Clark, G.; Barney, M. A., Corrosion, 2431 (2010)

74) DeVincentis, D. M.; Goff, S. P.; Slusser, J. W.; Zrecki, Z., Corrosion, 198 (1993)

75) Spiegel, M.; Warnecke, R., Corrosion, 01182 (2001)

76) Kawahara, Y.; Kira, M., Corrosion, 53, 241 (1994)

77) Yamada, K.; Tomono, Y.; Morimoto, J.: Sasaki, Y.; Ohmori, A., Vacuum, 65, 533-540 (2002)

78) Torrell, M., Corros. Eng., Sci. Technol., 45(1), (2010)

79) New Energy and Industrial Technology Development Organization, http://www.nedo.go.jp/ content/100087255.pdf (Last accessed July 21, 2016)：国立研究開発法人新エネルギー・産業技術総 合開発機構, 高効率廃棄物発電技術開発「従来型入 トーカ炉発電等高効率化技術開発」事業原簿, http:// www.nedo.go.jp/content/100087255.pdf(最終アクセス 日: 2016.7.21)

80) Uusitalo, M. A.; Vuoristo, P. M. J.; Mantyla, T. A., Corros. Sci., 46, (2004)

81) Sasaki, Y.; Naganuma, H.; Noguchi, M.; Cho, H.; Ninomiya, Y.; Chen, J.; Naruse, I.; Yoshiie, R.; Ueki, Y., 23th J. Jpn. Inst. Energy Conference, 260-261 (2014): 佐々木 頼明, 長沼 宏, 野口 学, 長 洋光, 二宮 善彦, J. Chen，成瀬 一郎，義家 亮，植木 保昭，第 23 回日 本エネルギー学会大会, 260-261, 2014 